\title{
The poor, the rich and the happy: Exploring the link between income and subjective well-being ${ }^{1}$
}

\author{
Emmanouil Mentzakis ${ }^{\mathrm{a},{ }^{*}}$ and Mirko Moro ${ }^{\mathrm{b}}$ \\ ${ }^{a}$ Health Economics Research Unit, University of Aberdeen, Aberdeen AB25 2ZD, UK \\ ${ }^{\mathrm{b}}$ University College Dublin, UCD Richview, Dublin 14,
}

\begin{abstract}
The relationship between income and subjective well-being (SWB) is investigated using eight waves of the British Household Panel Survey and an estimation strategy that allows us to relax some assumptions typically made in the literature. First, we use a random effects generalized ordered probit model to investigate whether income effects are heterogeneous across SWB categories, and, second, we discretise (absolute and relative) income variables to allow for the income effects to vary across income groups. We find that higher absolute income increases SWB but up to a certain level, while low income is significantly correlated with low scores in the SWB ladder. Our results are consistent with the Easterlin Paradox that has been reported in the literature. We find that high-income groups are less likely to belong in the highest SWB level, which could be partly explained by the fact that the relative income status (rather than the absolute one) is more important in determining (the highest level of) SWB.
\end{abstract}

Keywords: well-being; happiness; income; relative income; generalized models; heterogeneity JEL: I31, C23

\footnotetext{
${ }^{1}$ We wish to thank an anonymous referee, Wiji Arulampalam, Stefan Boes, Robert F. Elliott, Susana Ferreira, Matthew Sutton and Jeffrey M. Wooldridge for their valuable suggestions. The usual disclaimer applies.

* Corresponding author: Tel.: +44 (0) 1224 555189; Fax: +44 (0) 1224 550926; E-mail address: e.mentzakis@abdn.ac.uk
} 


\section{Introduction}

A large and growing empirical literature in economics is focused on understanding the determinants of individual well-being using happiness or subjective well-being ${ }^{2,3}$ (SWB) functions (for recent reviews see Frey and Stutzer 2002; Frey and Stutzer, 2005; Di Tella and MacCullogh, 2006, Clark et al., 2008). Since the early stages, the relationship that attracted the attention of economists was the one between income and happiness, which also bore important policy implications. The level of consumption associated with a positive level of income is often taken as one of the main components in the utility function and measures of individual and national income have been taken as proxies for the health of individual and societal growth over time (see a critic overview of these concepts in England (1988) and for a more general and macroeconomic standpoint see Boskin (2000) and Nordhaus (2000)).

In a similar fashion we continue to address the same relationship between income and happiness by combining two different strands of the current literature. On one hand, comparison and adaptation effects are incorporated into the analysis, by including selfperceived financial situation, while controlling for absolute income (and accounting for potential problems of endogeneity). On the other hand, we explore income heterogeneity in SWB across outcome categories and income groups, to test, among other things, whether the effects typically found in the literature (i.e., slightly positive effects on happiness) are insensitive to individual's income level.

The paper is structured as follows. Section 2 presents the background and previous literature, while it introduces in greater detail the contributions of the current paper. Section 3 presents the econometric methodology and Section 4 the data used in the analysis and the transformation of the variables. Section 5 presents the estimation results and Section 6 discussed them, while the Section 7 concludes with a summary of the findings and thoughts for further research.

\footnotetext{
${ }^{2}$ As is common in the literature, the terms happiness and subjective well-being are used interchangeably.

${ }^{3}$ The latent SWB is typically measured as a categorical variable derived directly from questions such as: "How dissatisfied or satisfied are you with your life overall", with a number of possible outcomes ranging from 'not satisfied' to 'completely satisfied'.
} 


\section{Background and motivation}

The discussion behind the income-happiness relation is, to a large extent, driven by the so-called 'Easterlin Paradox' (Easterlin, 1974; Easterlin, 1995), which lies in the fact that within a country, at a given time, those with higher incomes are, on average, happier, while over time and in the long run, despite increases in income in developed countries, the average level of happiness has not increased significantly. ${ }^{4}$ In, Easterlin's words, raising the income of all does not increase the happiness of all (Easterlin, 1995). Similar findings have been observed even more recently by Blanchflower and Oswald (2004) for the UK and the USA. Attempts to understand the Easterlin Paradox have put forward hypotheses related to hedonic adaptation, aspiration, comparison effects and time-use shift as very important determinants of well-being that should be included in the SWB regression.

Hedonic adaptation implies that perceived well-being can adapt to material goods over time at the same rate as income increase, thus, even if additional material goods provide initial pleasure, their effects wear out over time. Hence, people get used to their consumption and income levels (Scitovsky 1976; Easterlin 1974 and 1995). Similarly, aspiration or expectation effects relate to the fact that over the years the positive effects of increased income disappear as individuals adjust their aspirations accordingly (Easterlin, 2001; Stutzer, 2004; van Praag and Ferrer-i-Carbonell, 2004). Comparison effects suggest that in evaluating their financial situation, individuals compare themselves to their peers; as a result absolute income increases could be virtually cancelled out by comparison effects (Van de Stadt et al., 1985; Clark and Oswald, 1996; McBride, 2001; Ferrer-i-Carbonell, 2005; Vendrik and Woltjer, 2007). Therefore, it might be the difference between one's earnings and his/her peers (relative income) that can explain

\footnotetext{
${ }^{4}$ The most common examples are that of U.S.A. and Japan. During the period 1972-1991 US real GDP per capita more than doubled, yet levels of happiness remained constant. Similarly, Japan experienced a constant and stable economic growth, from the end of 1950s to the end of 1990s, with GDP per capita increasing five-folds, while there was no increase in the long run level in SWB. Almost the same conclusions hold for countries in Europe (Clark et al, 2008)
} 
SWB more precisely, rather than comparisons of absolute income. In general, relative income is evaluated as the average income of a reference group, defined exogenously by the researchers based on several criteria (e.g. region, age, education and gender), while whom individuals really compare themselves to remains unknown. Thus, a subjective element in defining relative income is introduced, as the researcher has to speculate about one's reference group.

Finally, Kahneman and his colleagues put forward another interesting interpretation related to time-use shifts. Rises in income often shift an individual's time use towards activities associated with a deterioration in SWB. The activities in which wealthier people spend relatively more of their time are associated, on average, with slightly higher tension and stress (Kahneman et al., 2006)

Moving away from the Easterlin paradox, a part of the literature is devoted in exploring how income affects happiness among different groups suggesting that the slope of the happiness-income relationship might vary (Frijters et al 2004a; Lelkes, 2006; Clark et al 2005). Clark et al. (2005) investigate slope heterogeneity using a latent class approach. Identifying the optimal number of latent groups and the probability of belonging to each latent class for each individual, they estimate the parameters of interest for each latent class, where significantly different marginal effects of income on SWB were found for each class. Furthermore, in two working papers, Boes and Winkelmann (2004, 2006a) allow the coefficient of income to vary across the response categories and find that lower SWB levels are positively affected by income while a negative effect is reported for the highest SWB levels suggesting that "income buys happiness up to a certain level"(Boes and Winkelmann, 2004, p. 2).

Recent studies based on longitudinal samples, allow for unobserved individual heterogeneity by including individual nuisance parameters (such as personality traits and reference scale bias), arguing for a positive relation between income and happiness (Kahneman et al., 2006). Winkelmann and Winkelmann (1998) used a fixed effects logit

\footnotetext{
${ }^{5}$ Time-shifts towards less enjoyable activities are explained by the failure in anticipating the effect of some activities on life satisfaction which is called focusing illusion by Kahnemann et al. (2006). A focusing illusion occurs when people concentrate on the influence of any single factor on their global well-being and exaggerate its importance relative to factors contributing to moment-to-moment happiness.
} 
model collapsing the SWB categories into a binary indicator of 'unhappy' and 'happy' people. Similarly, Ferrer-i-Carbonell and Frijters (2004), keeping then the ordinal nature of the SWB variables, estimate a fixed effects ordered logit model, while Ferrer-iCarbonell (2005) made use of a random effects ordered probit model allowing for some correlation between the individual characteristics and the observable variables.

Furthermore, a number of studies have been able to utilise exogenous variations in income to more firmly establish the causal and positive link between income and happiness (Ravallion and Lokshin, 2001; Frijters et al., 2004a, 2004b; Senik, 2004; Gardner and Oswald, 2006; Kahnemann et al., 2006). Gardner and Oswald (2006) compare individuals who won at the lottery with two control groups using a longitudinal data of British people and found that the unexpected increase in income had a positive effect on their mental health. Frijters et al (2004a; 2004b) found that 35-40\% of the increase in SWB in East Germans is due to the exogenous increase in real household income after the reunification of the country in 1991.

As argued in Section 1, the objective of this paper is to combine the literature on comparison, adaptation and expectation effects (used to explain the Easterlin Paradox) with the investigation of heterogeneity in SWB across for the British population, using the British Household Panel Survey (BHPS). The novelty of our approach lies in the methodology used that allows us to test for the importance of income on SWB in UK by relaxing several assumptions implicitly made when modelling the relationship between SWB and income.

First, apart from absolute income, we include in our estimations an original concept of 'relative income' based on the respondent's perceived financial status, which we assume to be a synthetic indicator that includes adaptation and comparison effects. As previously mentioned, happiness studies assess relative or comparison income effects on happiness by assigning a reference group to every individual, where these reference groups are defined in terms of age, education and possibly region and are common across the sample (see for example Ferrer-i-Carbonell, 2005). Arguably the choice of the reference group is arbitrary. There are other unobserved factors that influence what the individuals would consider as their reference group rendering impossible to evaluate the criteria used to build these reference groups. We argue that respondents are the best 
judges of their own situation and that in the absence of information about each individual's reference group, a subjective assessment of financial status (or situation) by each respondent might incorporate more efficiently how individuals evaluate their household income relative to their "true" reference group. In sum, rather than imposing the common criteria for the choice of reference group, we allow respondents' perception of their financial situation to be the indicator of their relative income. Moreover, subjective perception of financial situation includes an evaluation of the respondent's current income with respect to his past circumstances and aspirations. Our notion of relative income is linked to the theoretically and empirically well-grounded concept for individual's aspirations, where individual welfare functions are constructed by asking the respondents to evaluate different levels of income as 'bad', 'good', etc. (van Praag, 1971, 1993). In answering the 'income evaluation question', they should take into account their own situation with respect to their past and peers.

Second, we focus on analysing the slope heterogeneity of the happiness-income relationship (Boes and Winkelmann 2004; 2006a; 2006b; Clark et al., 2005), which implies allowing individual utility function to differ across individuals (Tinbergen, 1991; Sen, 1992). Specifically, studies (Huppert and Whittington, 2003) have shown a degree of independence in the determinants of positive and negative well-being, indicating that ill-being and well-being are two distinct dimensions and not opposite ends of the same scale (p.S24, Headey and Wooden, 2004). Hence, though, the ordinal nature of the SWB variables is maintained the implicit assumption of the traditional ordered response models of homogeneity of the regressors' effects for each level of subjective well-being is relaxed. We test for the importance of income effects allowing for flexible estimated parameters across the distribution of the outcome variable, which could provide interesting insights in the income-happiness relationship. This specification possesses several advantages when compared to the specifications typically used in the literature as it enhances greatly the flexibility and the amount of information that can be extracted from the data, as well as allowing for the computation of marginal effects, easing the interpretation of the parameters for nonlinear models. In particular, contrary to the standard ordered probit, the marginal effects for the generalised ordered probit are not constrained to switch sign exactly once, when moving from the lowest to the highest 
SWB category, but the effects are freely determined by the model (Winkelmann and Boes, 2006).

Third, we test if our findings hold when considering heterogeneous groups of people. We introduce (absolute and relative) income as categorical variables allowing for different effects to be observed across income groups and also relaxing any aprioristic linear functional form assumption. This specification permits testing whether the direction and magnitude of income effects on the different level of happiness are similar across poor and rich (i.e., whether poor and rich react alike to income changes) and whether the conclusions of the current literature regarding the existence of both absolute and relative income effects hold for different segments of the income distribution.

Fourth, we reduce the problem of potential endogeneity. As mentioned previously, there are few studies (Frijters et al., 2004a; 2004b; Gardner and Oswald, 2006) adequately addressing this issue in the SWB literature. However, in doing so, they focus on sub-samples of the population (i.e., lottery winners) and their results cannot be adopted and generalised when the main interest lies in the income-happiness relationship in the general population. In order to account for endogeneity, we make use of the panel structure of our dataset and introduce in the models the lagged values of the suspected endogenous variables (employment status and health conditions), treating them as predetermined.

\section{Methods}

The nature of our dependent variable (SWB with 6 ordered outcomes) compels us to employ ordered response models for our modelling purposes. By assuming that happiness is a linear function of certain variables, the model to be estimated is of the form:

$$
\begin{aligned}
& y_{i t}^{*}=\beta x_{i t}+\mu_{i}+\varepsilon_{i t} \\
& y_{i t}=j \text { if } \quad \xi_{\mathrm{j}-1}<y_{i t}^{*} \leq \xi_{j}, \quad \text { for } j=1, \ldots, J
\end{aligned}
$$


where, $i=1, \ldots, n$ and $t=1, \ldots, T$ denoting individuals and time, respectively. $y_{i t}^{*}$ reveals the latent process of happiness and it is linked to the observed outcome $y_{i t}$, given by the SWB question, as presented in equation 2. $\mu_{i}$, is the time invariant individual parameter assumed to be uncorrelated with any of the regressors (something that will be relaxed later on), and $\varepsilon_{i t}$ is the normally distributed random error assumed to be strictly exogenous, capturing the unobserved heterogeneity for happiness. The vector $x_{i t}$ includes all the variables of interest while it is assumed to be exogenous conditional on $\mu_{i}$. Finally, as said previously we only observe $y_{i t}$, which takes the discrete values $j=1, \ldots, 6$, where the cut-off points $\left(\xi_{j}\right)$ need to be estimated along with the rest of the parameters.

Following from the equations (1) and (2), the predicted probability for the ordered probit conditioning on $\mu_{i}$ is

$$
\operatorname{Pr}\left(y_{i t}=j \mid x_{i t}, \mu_{i}\right)=\Phi\left(\xi_{\mathrm{j}}-\beta x_{i t}-\mu_{i}\right)-\Phi\left(\xi_{j-1}-\beta x_{i t}-\mu_{i}\right)
$$

where $\xi_{0}=-\infty$ and $\xi_{J}=\infty$ with $\Phi\left(\xi_{0}\right)=0$ and $\Phi\left(\xi_{J}\right)=1$, while $\Phi$ denotes the standard normal cumulative function where without loss of generality the variance is equal to 1 .

However, the random effects ordered probit model presented above, although it takes into account the repeated observations and the heterogeneity unobserved to the researcher, it has a fundamental limitation. The assumption of the model, referred to as single crossing property, requires that as we move from the probability of the smallest outcome to the probability of the largest outcome, the marginal probability effects are allowed to change their sign (effect) once (Boes and Winkelman, 2006). Borrowing from Long and Freese (2005), the ordered response model is equivalent to $j-1$ binary regressions, assuming that the slope coefficient for each regressor is constant across regressions (i.e. parallel lines assumption). 


$$
\begin{aligned}
& \operatorname{Pr}\left(y_{i t} \leq 1 \mid x_{i t}, \mu_{i}\right)=\Phi\left(\xi_{1}-\beta x_{i t}-\mu_{i}\right) \\
& \operatorname{Pr}\left(y_{i t} \leq 2 \mid x_{i t}, \mu_{i}\right)=\Phi\left(\xi_{2}-\beta x_{i t}-\mu_{i}\right) \\
& \vdots \\
& \operatorname{Pr}\left(y_{i t} \leq J-1 \mid x_{i t}, \mu_{i}\right)=\Phi\left(\xi_{\mathrm{j}-1}-\beta x_{i t}-\mu_{i}\right)
\end{aligned}
$$

This assumption can be formally tested through Log-likelihood ratio (LR) tests (Long and Freese, 2005) and its rejection indicates the need to permit the cut-off points to be linear functions of the regressors of interest (Maddala, 1983; Terza, 1985; Boes and Winkelman, 2006), in our case income, and thus allowing the model to follow and represent human behaviour more efficiently.

$$
\xi_{i j}=k_{j}+\gamma_{j} z_{i t}
$$

where $z_{i t}$ is a vector including the income variables. From equations (4) and (5), conditioning on the time invariant individual component, $\mu_{i}$, the conditional probabilities become $^{6}$ :

$$
\begin{aligned}
\operatorname{Pr}\left(y_{i t}=j \mid x_{i t}, \mu_{i j}\right)= & \Phi\left(\kappa_{j}-\beta_{j} z_{i t}-\beta x_{i t}-\mu_{i j}\right) \\
& -\Phi\left(\kappa_{j-1}-\beta_{j} z_{i t}-\beta x_{i t}-\mu_{i j}\right) \quad \text { for } \quad j=1, \ldots, J
\end{aligned}
$$

where $\beta_{j}=\beta-\gamma_{j}$, which cannot be separately identified, while the properties of equation (3) still hold. $x_{i t}$ and $z_{i t}$ are assumed to be exogenous conditional on $\mu_{i j}$.

Treating $\mu_{i j}$ as fixed parameters to be estimated, with a large number of individuals and fixed number of time periods, introduces incidental parameters problem (Lancaster 2000; Wooldridge, 2002, 2005; Greene, 2004), biasing the estimated coefficients. Therefore, we use a random effects specification and following Mundlak (1978) and Chamberlain (1982) we relax the assumption of no correlation among $\mu_{i j}$ and the

\footnotetext{
${ }^{6}$ The generalized random effects ordered probit model was estimated in Stata SE 9.2 using the user-written routine -regoprob- by Stephan Boes (http://econpapers.repec.org/software/bocbocode/s456604.htm).
} 
covariates. In doing so we parameterise $\mu_{i j}$ by conditioning the distribution of the unobserved effect on the exogenous independent variables.

$$
\mu_{i j}=\mu_{j}\left(\bar{x}_{i}+\bar{z}_{i}\right)+v_{i}
$$

where $\bar{x}_{i}$ and $\bar{z}_{i}$ are the averages of the exogenous regressors over the sample period, while $v_{i}$ is the individual specific error, where $v_{i} \mid x_{i} \sim N\left(0, \sigma_{v}^{2}\right)$ and independent of the idiosyncratic error $\varepsilon_{i t}$. The coefficients of time-invariant variables cannot be disentangled from $\mu_{i j}$ in equation 6 and their inclusion is not meaningful (Wooldridge, 2002). Hence, we follow a split sample analysis to distinguish the behaviours of the two genders. Initially, we estimate a model where only absolute income is included and then a model where absolute and relative incomes are included together.

For the interpretation of our estimation results we use marginal effects. Since, all the variables of interest (absolute and relative income) are binary indicators it would be more appropriate to talk about discrete changes, which are the changes in the predicted probability for a change in income class (or financial situation) holding all the other variables constant and other income classes (or financial situations) at zero. For the generalized random effects ordered probit the discrete change ${ }^{7}$ can be written formally as:

$$
\Delta \operatorname{Pr}\left(y_{i t}=j \mid \bar{x}_{i t}, \bar{\mu}_{i t}\right) / \Delta z_{k}=\operatorname{Pr}\left(y_{i t}=j \mid \bar{x}_{i t}, \bar{\mu}_{i j}, z_{k}=1\right)-\operatorname{Pr}\left(y_{i t}=j \mid \bar{x}_{i t}, \bar{\mu}_{i j}, z_{k}=0\right)
$$

\section{Data}

For this study we use the British household Panel Survey (BHPS), for the years 1996 to 2003. The BHPS is an annual longitudinal survey carried out by the ESRC UK

\footnotetext{
${ }^{7}$ For the computation of discrete changes, population average parameters $\beta_{a}=\beta^{*}\left(1+\sigma_{v}^{2}\right)^{-1 / 2}$ were used (Wooldridge, 2005). They allow for comparisons between estimations from pooled and panel specifications, which otherwise have different error variances, resulting in different scaling of the coefficients.
} 
Longitudinal Studies Centre with the Institute for Social and Economic Research at the University of Essex, which targets individuals of the age of 16 and over. As is often the case, the SWB measure is derived by the question, "How dissatisfied or satisfied are you with your life overall", with 7 possible outcomes ranging from "not satisfied at all" to "completely satisfied". Due to low incidence rates the first two outcomes were aggregate and the distribution of the variable for males and females is presented in Fig. 1. It is evident that the distribution is skewed to the right, meaning that most of the people in our sample (around 60\%-65\%) have a level of SWB close to the highest level. Table 1 shows average SWB by income which ranges from 4.01 to 4.49 for female and from 4.12 to 4.41 for male. SWB scores increase as income increases for both genders.

As indicators of absolute income we use categorical equivalised annual household income with five levels representing the quintiles of its distribution (see e.g., Alesina et al., 2004; Blanchflower and Oswald, 2004; Vendrik and Woltjer, 2007). Because the first and the fifth income quintiles aggregate very heterogeneous groups (from $£ 0$ to $£ 10,360$ per year for the first and from $£ 30,000$ to $£ 248,000$ per year for the last $)^{8}$, we further divided them into two subgroups each accounting $10 \%$ of the income distribution, giving us a total of seven income status segments. For the equivalisation we employ the McClements (1977) equivalisation scale, which was provided in the raw data. It is clear, that happiness for an individual is very much dependent on their income after taking into consideration the size and composition of their household and hence, two individuals stating the same household income do not belong in the same income category if one of them is single, thus having his total income at his disposal, and the other one is married with children, thus in need to share his income across the members of the family. Table 2 shows some descriptive statistics of income dummies by gender and how they relate to the original continuous equivalised income variable. As already described income was collapsed into 7 categories (without distinguishing among male and female). The minimum and maximum levels of income are displayed for each income group in order to show the relative dispersion. The first income group includes people with income varying between $£ 0$ and $£ 7,505$, the second income group includes equivalised income ranging

\footnotetext{
${ }^{8} 47$ observations with annual income greater then $250,000 £$ were dropped as outliers.
} 
among $£ 7,506$ to $£ 10,366$ and so on. It follows, that median income is included in the $4^{\text {th }}$ income class by design. The average income is slightly higher than the median income for both genders and the income differences among genders are tiny in each income group, while males have a slightly higher average income in every income class but the $5^{\text {th }}$. The average income for males is $£ 23,987$ while for females is $£ 22,892$.

Perceived financial situation is used as a proxy of relative individual income under the assumption that when people characterise their financial situation they take into account their feelings about their situation which might be influenced by their past situations, by the situation of their peers and by various environmental factors. Perceived financial situation is, thus, extracted by the question, "How well would you say you yourself are managing financially these days? Would you say you are..." with 5 potential different outcomes: "Finding it very difficult", "Finding it quite difficult", "Just about getting by", "Doing alright" and "Living comfortably". Table 3 presents the distribution of the perceived financial situation variable (i.e. relative income). We can see that almost the same percentage of female and male (38\% and 37\%, respectively) reports themselves as "doing alright" (the $4^{\text {th }}$ category), followed by $31 \%-32 \%$ of people that declare of being at the highest category. The correlation matrices for female and male in table 4 show that absolute income and perceived relative income are just slightly correlated. In particular, those who belong to the first three income groups are more likely to report "just about getting by" and "finding it very difficult", but the relationship is weak and decreasing as we move along the financial situation and income classes. Belonging to the highest income classes is negatively correlated with low perceived financial status.

As confounding factors a set of individual socio-demographic characteristics, common in the previous literature (Helliwell, 2002; Ferrer-i-Carbonell and Frijters, 2004), are included in each model specification. In particular we add age, household size, number of kids, education and marital status, as well as, controlling for endogeneity, the lagged values of self-assessed health and unemployment. Moreover, in order to account for spatial and temporal heterogeneity a set of binary indicators capturing the region fixed effects and a set of time-dummies were also included in the model estimations.

\section{Estimation results}


As discussed in section 3, LR-tests were run to check for the appropriateness of the parallel lines assumption. The equality of the coefficients across outcome categories can be rejected at $1 \%$ significance level in every case ${ }^{9}$. Thus, estimations for the traditional random effects ordered probit are not discussed any further ${ }^{10}$. Moreover, as the coefficients from ordered response models provide indication only for the direction of an effect but not for its magnitude, we concentrate on the marginal effects for the generalised models, where the parameters are interpreted as discrete changes computed as in equation (10), keeping the median category as the reference group.

Table 5 presents the results of the models that include absolute income as covariates but not relative income. We see the three lowest income categories having a higher probability of reporting low SWB (levels 1 to 3), although with particularly low statistical significance. Similarly, insignificant parameters are observed for the rich in the first three SWB categories, with the exception of the negative significant ai6 and ai7 for SWB level $3^{11}$.

Moving to SWB levels 4 and 5, which are the relatively most common in the sample, we observe a change of behaviour, with individuals of low income reporting being less likely to belong in them (2-5 percentage points, p.p. ${ }^{12}$, decrease relative to the base) and for the richest a corresponding increase in probability of 5-6 p.p. Especially for SWB level 4, statistical significance lies with the low income groups, while for SWB level 5 the effect is more robust across the whole distribution, with magnitudes ranging from -5.3. to 6.4 p.p. for females and from -8.3 to 6.2 p.p. for males, revealing a broad heterogeneity across income groups. Most importantly, the wealthiest males behave in a

\footnotetext{
${ }^{9}$ The null hypothesis of equal slope for all income dummies across SWB categories was rejected for female, $\mathrm{LR}_{252}=1519$, and male, $\mathrm{LR}_{252}=1250$, in models with absolute income, excluding relative income. Similarly for models with absolute and relative income groups included, the rejection of the null was reported with $\mathrm{LR}_{83}=1614$ and $\mathrm{LR}_{83}=1613$ for females and males, respectively.

${ }^{10}$ Estimation results for the ordered probit models are available from the authors upon request.

${ }^{11}$ For notational simplicity in the text and tables we use ai1, ai2, ai3, etc., to define the absolute income groups considered, while fs1, fs2, etc., to define the relative income (financial situation) groups.

${ }^{12}$ Due to the frequent use of the term "percentage points", we abbreviate it to "p.p.".
} 
similar manner to the poor, with a negative probability of 3.1 and 7 p.p. of belonging to SWB levels 4 and 5, respectively.

On the other hand, the discrete changes for the final column, $J=6$, show consistently and for both genders, low income individuals to be more likely to report the happiest category, with the second poorest (ai2) having the highest chance of all, with 4.7 p.p. and 6.1 p.p. relative to the base (median) income group, for females and males, respectively. Belonging in high income classes, negatively affects the probability of reporting the highest level of SWB, with the probability decreasing of about 2 p.p. (or 3) for female (or male) in the $5^{\text {th }}$ income class and by about 3 p.p. for the $6^{\text {th }}$ and $7^{\text {th }}$ for female, while slightly larger figures are reported for male ( 7 p.p. for the $6^{\text {th }}$ and 5 p.p. for the $\left.7^{\text {th }}\right)$.

Moving on to Table 6, we present the marginal effects of the models including both absolute and relative income. For $J=1$ to 4 , there is a general lack of significance with the exception of the richest individuals, who are less likely to belong to SWB level 3, something that holds for both genders. Looking at SWB level 6, low income individuals have an increased probability of about 2-4 p.p. relative to the base in reporting $J=6$, with the second poorest (ai2) having the highest probability (5.7 and 4.5 p.p. for females and males respectively) of all. On the contrary, high income individuals, face a decreased probability by a similar amount.

Turning to the relative income (subjective financial situation) variables, poor individuals of both genders are more likely to report the first three SWB levels, with those being not satisfied with their own financial situation facing an increased probability of reporting "completely dissatisfied" with life by a significant 7 p.p. Poverty, both defined as absolute and relative, is strongly associated with low levels of SWB. Furthermore, the probability associated with reporting the relatively most common SWB levels, $J=4$ and $J=5$, decreases considerably for the poor although, it is significant only for the latter. SWB level 5 is more probably to be observed for wealthy individuals (5.5 and 8.6 p.p. for females and 5.6 and 6.4 p.p. for males, according to income group), while there is a striking symmetry of the coefficients for females.

It is important to note the conditional interpretation of our results. The discrete probability effects for absolute income give the changes in the probability for a particular 
SWB level conditional on the fact that relative income remains unchanged. For females in $J=5$, a change from ai4 to ai6 increase the probability of $J=5$ by 5.2 p.p. when financial situation remains the same. However, a simultaneous change from fs 1 to fs 2 creates an additional increase in the probability of $J=5$ by about 2.6 p.p. (-0.0555-($0.0816)=0.0261)$.

At last, higher categories of financial situation have a negative (although not significant) effect on the probability of being happier. Reporting a satisfying financial situation is related to negative chances of having low SWB and positive chances of scoring high SWB. In other words, the richest, in terms of relative income, report themselves to be the happiest. The latter result, however, is statistically significant only for the people belonging to the highest relative category, "living comfortably", and not for those who are "doing alright". Although this result is opposite to what we found in relation to absolute income, it agrees with the finding in Table 5 that the richest males are most likely to be among the happiest individuals.

\section{Discussion}

As is clear from our results, different dimensions of the income-happiness relationship can be detected by looking at SWB and income distributions, i.e., along the horizontal and vertical axes of Table 5 and 6, respectively, while no differences are revealed from gender comparisons.

Looking at Tables 5 and 6, distinctive patterns emerge between poor and rich (relative to the median income class), whose effects have always opposite directions. These patterns have been stylised for ease of exposition in Fig. 2, which is divided in two parts, with the upper part illustrating the effects of absolute income on SWB, while the lower part illustrates the effects of relative income. The vertical lines represent SWB thresholds while the horizontal lines represent low and high income group. The minus and plus signs identify the likelihood of reporting the SWB levels reported in each column (with respect to the median class).

Summarising the identified behaviour for absolute income we have collapsed the SWB levels in three labels 'dissatisfied' $(J=1,2$ and 3), 'satisfied' ( $J=4$ and 5) 
'completely satisfied' $(J=6)$. This finding is not affected by the inclusion or exclusion of relative income. Low income people are more likely to not be satisfied with their lives; while higher income people are less likely to report low happiness levels. For the sake of simplicity, we could stylise this finding by saying that "income buys off unhappiness"13,14. Looking at the fact that wealthier individuals are more likely to report more satisfaction with their life than those with lower income situations we could argue that income not only buys off un-happiness, but also it buys a big portion of happiness. As Fig. 1 shows, more than half of our sample is concentrated here, reporting SWB levels of either 4 or 5 . Up to now, our findings confirm the bulk of the literature on the positive relationship between income and happiness (see section 2). However, does income buy all the happiness? The third column of the upper part of Fig. 2 shows the likelihood of reporting the highest level of SWB. Paradoxically, belonging to high income group decreases the probability of reporting the highest level of SWB, indicating that income buys happiness, but up to a point. In support of this argument comes another unexpected finding; the fact that lower income individuals are more likely to report "completely satisfied" with their life.

Explanations for these paradoxes can be found in the literature on the presence of hedonic adaptations, aspirations and comparison effects dating back to Veblen (1899), Duesenberry (1949), Easterlin (1975) and, more recently, Frank (1997) and Easterlin (2001) and relating to the ideas of interdependence of preferences and the consequent positional externalities. Inclusion of perceived financial situation (relative income) capturing the aforementioned effects confirms the idea that relative income matters. The importance of relative income is also apparent in our data. Previous studies (Van de Stadt et al., 1985; Clark and Oswald, 1996; McBride, 2001; Stutzer, 2004; Ferrer-i-Carbonell, 2005; Vendrik and Woltjer, 2007) have also consistently found income relative to individual's own past (adaptation effects), future (aspiration or expectation effects) and peers (comparison effects) to be as important as absolute income in determining

\footnotetext{
13 "Do you know what I do about unhappiness? I buy it off”, Psycho, Alfred Hitchcock, 1960 (screenplay by Joseph Stefano): This concept permeates popular culture giving birth to many ways of expressing the same meaning.

${ }^{14}$ Here for simplicity of exposition, "unhappiness" is defined as the first three levels of SWB.
} 
subjective well-being, with the relative income effects even cancelling out the effects on SWB brought about by absolute income growth.

As discussed in sections 2 and 4, we include perceived financial situation as a proxy for relative income in our models. The lower part of Fig. 2 shows that the effects of relative income, controlling for absolute income, appears to have a linear effect on happiness. Low relative income individuals are more probable to report low levels of SWB, while wealthier individuals are more likely to report high level of SWB. Contrary to absolute income, relative income brings the highest level of happiness $(J=6)$, whereas for all other income groups, relative income is not the mean to achieve happiness. This finding could be a corollary of the fact that how rich is someone is more accurately measured by his relative income and that truly rich are those appearing in high relative income groups. We should mention that this implies that people with low absolute income can report the highest relative income and this is exactly due to the surroundings that affect ones perception of wealth.

Furthermore, looking at relative income, there is weak evidence for heterogeneous SWB threshold points between different relative income groups, revealing different notions of satisfaction between rich and poor. This is shown by the discontinuous vertical line in the lower part of Fig. 2. It is possible, that heterogeneity in how happiness is defined among individuals is a reason for observing the last relative income group, fs5, to report highly significant and negative discrete effects, the same as fs1. Finally, considering the magnitude of the discrete changes on the various probabilities we find that in the majority of cases relative income appears to be at least as influential as absolute income, further supporting the argument for the importance of relative income when one evaluates their well-being.

Another explanation of these paradoxes, commonly put forward, refers to the literature about social capital, relational goods, and hedonic psychology (Kahnemann et al., 1999; Helliwell, 2006). High-income individuals are more likely to have jobs of high responsibility and to allocate their time to activities that are on average associated with more stress and tension, e.g. commuting, (Frey and Stutzer, 2002), or less likely to spend their time in socialising, which is among the most rewarding activities in terms of happiness (Kahnemann et al., 2004; Kahnemann et al., 2006). Conversely, low income 
groups might not have any difficulty in accessing these goods, explaining why a portion of the low income group is likely to report the highest level of SWB.

However, such interpretations make strong assumptions about the causality of the observed effects. Our adoption of the Mundlak (1978) approach allows us to avoid estimation of biased parameters in the presence of time-invariant unobserved factors that are causally related to SWB and non-causally linked to income generation. However, the existence of unobserved time-varying factors that lead to loss of SWB and also generate higher income (e.g. stressful jobs lead to lower SWB but generate high income) leads to biased estimates of the effect of income per se on SWB. In other cases (e.g. where higher income people indulge in more health-harming activities) these unobserved factors should be viewed as part of the causal link between higher income and lower SWB. Therefore, statements about the presence of a direct causal relationship between income and SWB should be treated with caution because unobserved (time-varying) factors may present potential simultaneity problems (Adams et al., 2003).

\section{Conclusion}

In this paper we investigate the relationship between income and happiness using a generalised ordered probit model with a specification capable of distinguishing income effects on SWB across different income groups and different SWB levels. The variety of distinctive patterns derived is a direct result of our estimation strategy and specifically, due to the transformation of income variable into income dummies and the use of a generalized model.

The poor are more likely to be unhappy while the rich are more likely to be fairly happy. Absolute income buys-off unhappiness, but it does not seem to buy all levels of happiness. This can be explained by looking at relative income effects, through the inclusion of individuals' subjective financial situation which captures ones relative income position and clearly confirms the findings of the past literature. Our findings can

provide a framework for the rationalisation of the Easterlin paradox found within the UK (Blanchflower and Oswald, 2004). The paradox states that, in the long run, happiness does not follow increases in income, while when looking at a cross section of the 
population, the wealthier are happier. Turning at our results, we verify absolute income explaining the first part of the paradox, while relative income the latter and highlighting the importance of relative status as a determinant of well-being.

Another explanation of these findings, relates to the concept of time-shift effects, where high income individuals tend to engage in less satisfactory activities. Even though our model allows for correlation among individual (time-invariant) effects and income; the proposed explanation would run into simultaneity problems if factors that affect the loss of SWB contemporaneously affect income. Further research would be necessary focussing on these issues and including variables and instruments to control for the currently unobserved factors (e.g. social networks, job types, stress level, etc.).

Furthermore, our estimator could be improved by treating individual heterogeneity as fixed effects and specifying a generalised conditional fixed effects ordered logit; however, such models require stronger statistical assumptions and require even further assumptions to provide estimates for partial effects and average partial effects (Wooldridge, 2002, p. 492), which as we see are imperative for inference. Finally, in our study we relax as many restricting assumptions as possible and it would be necessary for this type of analysis to be replicated in order to test the robustness of the findings and whether they are country specific or widely generalisable.

\section{References}

Adams, P., Hurd, M.D., McFadden, D., Merrill, A., Ribeiro, T., 2003. Healthy, wealthy, and wise? Test for direct causal paths between health and socioeconomic status. Journal of Econometrics, 112, 3-56

Alesina, A.; Di Tella, R. and MacCulloch, R., 2004. "Inequality and Happiness: Are Europeans and Americans Different?” Journal of Public Economics, 88, 2009 - 2042.

Boes, S., Winkelman, R., 2004. Income and Happiness: New Results from Generalized Threshold and Sequential Models. Working Paper No. 0407, Socioeconomic Institute, University of Zurich 
Boes, S.,Winkelman, R., 2006a. The Effect of Income on Positive and Negative Subjective Well-Being. Working Papers 0605, Socioeconomic Institute, University of Zurich

Boes, S., Winkelmann, R., 2006b. Ordered Response Models. Allgemeines Statistisches Archiv 90(1), 165-180

Boskin , M. J., 2000. Getting the 21st-Century GDP Right: Economic Measurement:

Progress and Challenges. The American Economic Review, Papers and Proceedings of the One Hundred Twelfth Annual Meeting of the American Economic Association $90(2), 247-252$

Blanchflower, D., Oswald, A., 2004. Well-being over time in Britain and USA. Journal of Public Economics 88, 1359-1386

Bruni, L., Stanca, L., 2006. Income Aspirations, Television and Happiness: Evidence from the World Values Survey. Kyklos 59(2), 209-225

Chamberlain, G., 1982. Multivariate Regression Model for Panel Data. Journal of Econometrics 18, 5-46

Clark, A.E., Oswald, A.J., 1996. Satisfaction and Comparison Income. Journal of Public Economics 61,359-81

Clark, A.E., Etilé, F., Postel-Vinay, F., Senik, C., Van der Straeten, K., 2005. Heterogeneity in reported well-being: Evidence from twelve European countries. Economic Journal 115, C118-C132.

Clark, A.E., Frijters, P., Shields, M., 2008. Relative Income, Happiness and Utility: An Explanation for the Easterlin Paradox and Other Puzzles. Journal of Economic Literature 46 (1) , 95-144

Di Tella, R., MacCulloch, R.J., 2006. Some uses of happiness data in economics. Journal of Economic Perspectives 20 (1), 25 - 46

Duesenberry, J., 1946. Income, Saving, and the Theory of Consumer Behavior. Cambridge, MA: Harvard University Press

Easterlin, R., 1974. Does economic growth improve the human lot? Some empirical evidence. In: David, R., Reder, R. (Eds.). Nations and Households in Economic Growth: Essays in Honor of Moses Abramovitz, New York: Academic Press 
Easterlin, R., 1995. Will Raising the Incomes of All Increase the Happiness of All? Journal of Economic Behaviour and Organization 27, 35-48

Easterlin, R., 2001. Income and happiness: towards a unified theory. Economic Journal 111, 465-484

England, R., 1998. Measurement of social well-being: alternatives to gross domestic product. Ecological Economics 25(1), 89-103

Ferrer-i-Carbonell, A., Frijters, P., 2004. How Important is Methodology for the Estimates of the Determinants of Happiness. The Economic Journal 114 641-59

Ferrer-i-Carbonell, A., 2005. Income and well-being: An empirical analysis of the comparison income effect. Journal of Public Economics 89, 997-1019

Frank, R.H., 1997. The Frame of Reference as a Public Good. Economic Journal 107, $1832-1847$

Frank, R., 1999. Luxury Fever. Princeton, NJ: Princeton Univ. Press

Frey, B.S., Stutzer, A., 2002. What can economists learn from happiness research? Journal of Economic Literature 40(2), 402-35

Frey, B.S., Stutzer, A., 2005. Stress that Doesn't Pay: The Commuting Paradox. Review of Social Economy 62 (2), $207-28$

Frijters, P., Shields, M.A., Haisken-DeNew, J.P., 2004a. Money does matter! Evidence from increasing real incomes in East Germany following reunification. American Economic Review, 94, 730-741

Frijters, P., Shields, M.A., Haisken-DeNew, J.P., 2004b. Changes in the pattern and determinants of life satisfaction in Germany following reunification. Journal of Human Resources 39, 649-674

Gardner, J., Oswald, A.J., 2007. Money and mental wellbeing: A longitudinal study of medium-sized lottery wins. Journal of Health Economics 26(1), 49-60

Greene, W., 2004. Fixed effects and bias due to the incidental parameters problem in the tobit model. Econometric Reviews 23(2), 125-47

Headey, B.W., Wooden, M., 2004. The Effects of Wealth and Income on Subjective Well-Being and Ill-Being, The Economic Record 80, S24-S33

Helliwell, J., 2002. How's Life? Combining Individual And National Variables To Explain Subjective Well-Being, NBER Working Paper 9065. 
Helliwell, J., 2006. Well-Being, Social Capital and Public Policy: What's New?

Economic Journal 116(510), C34-C45

Huppert, F.A., Whittington, J.E., 2003. Evidence for the independence of positive and negative well-being: Implications for quality of life assessment, British Journal of Health Psychology, 8, 107-122.

Kahneman, D., Diener, E., Schwarz, N., Eds. 1999. Well-being: The foundations of hedonic psychology, Russell-Sage, New York, 1999, pp. 413-433.

Kahneman, D., Krueger A., Schkade D., Schwarz, N., Stone, A., 2004a. A survey method for characterizing daily life experience: the day reconstruction method. Science 306(5702), 1776-1780

Kahneman, D. Krueger, A.B., Schkade, D., Schwarz, N., Stone, A.A., 2006. Would You Be Happier If You Were Richer? A Focusing Illusion. Science 312(5782), 1908

Lancaster, T., 2000. The incidental parameter problem since 1948. Journal of Econometrics 95(2), 391-413

Lelkes, O., 2006. Tasting freedom: Happiness, religion and economic transition. Journal of Economic Behavior and Organization 59, 173-194

Long, J.S., Freese, J., 2005. Regression Models for Categorical Outcomes Using Stata. Second Edition. College Station, TX: Stata Press

Maddala, G.S., 1983. Limited-Dependent and Qualitative Variables in Econometrics. Cambridge, UK: Econometric Society Monographs in Quantitative Economics, Cambridge.

McBride, M., 2001. Relative income effects on subjective well-being in the cross-section. Journal of Economic Behaviour and Organization 45(3), 251-278

McClements, L., 1977. "Equivalence scales for children. Journal of Public Economics $8(2), 191-210$

Mundlak, Y., 1978. On the pooling of time series and cross-section data. Econometrica 1, 69-85

Nordhaus, W. D., 2000. New Directions in National Economic Accounting. The American Economic Review, Papers and Proceedings of the One Hundred Twelfth Annual Meeting of the American Economic Association 90(2), 259-263 
Ravallion, M., Lokshin, M., 2002. Self-rated economic welfare in Russia. EuropeanEconomic Review 46, 1453-1473

Scitovsky, T., 1976. The Joyless Economy. New York: Oxford University Press.

Sen, A. (1992). Inequality Reexamined, Oxford: Oxford University Press.

Senik, C., 2004. When information dominates comparison: A panel data analysis using Russian subjective data. Journal of Public Economic, 88, 2099-2123

Stutzer, A., 2004. The role of income aspirations in individual happiness. Journal of Economic Behavior and Organization 54, 89-109

Terza, J., 1985. Ordinal Probit: A Generalisation. Communications in Statistics - Theory and Methods 14, 1-11

Tinbergen, J., 1991. On the measurement of welfare. Journal of Econometrics 50, 7-15. van de Stadt, H., Kapteyn, A., Van de Geer, S., 1985. The relativity of utility: Evidence from panel data. Review of Economics and Statistics 67, 179-187

van Praag, B.M.S., 1971. The welfare function of income in Belgium: an empirical investigation. European Economic Review 2, 337-369

van Praag, B.M.S., 1993. The relativity of the welfare concept. In: Nussbaum, M., Sen, A.K. (Eds.), The Quality of Life. Clarendon: Oxford, pp. 362-416.

van Praag, B.M.S. and Ferrer-i-Carbonell, A., 2004. Happiness Quantified - a Satisfaction Calculus Approach. Oxford: Oxford University Press.

Veblen, T., 1899. The Theory of Leisure Class. Modern Library, New York.

Vendrik, M. and Geert, W.,2007. "Happiness and loss aversion: Is utility concave or convex in relative income?", Journal of Public Economics, 91, 1423-1448.

Winkelmann, L., R. Winkelmann., 1998. Why are the unemployed so unhappy? Evidence from panel data. Economica 65(257), 1-15

Winkelmann, R., Boes, S., 2006. Analysis of Microdata. Berlin: Springer.

Wooldridge, J.M., 2002. Econometric Analysis of Cross Section and Panel Data. Cambridge, MA: The MIT Press.

Wooldridge, J.M., 2005. Simple solutions to the initial conditions problem in dynamic, nonlinear panel data models with unobserved heterogeneity. Journal of Applied Econometrics 20(1), 39-54 
Fig. 1. Distribution of SWB across response categories by gender
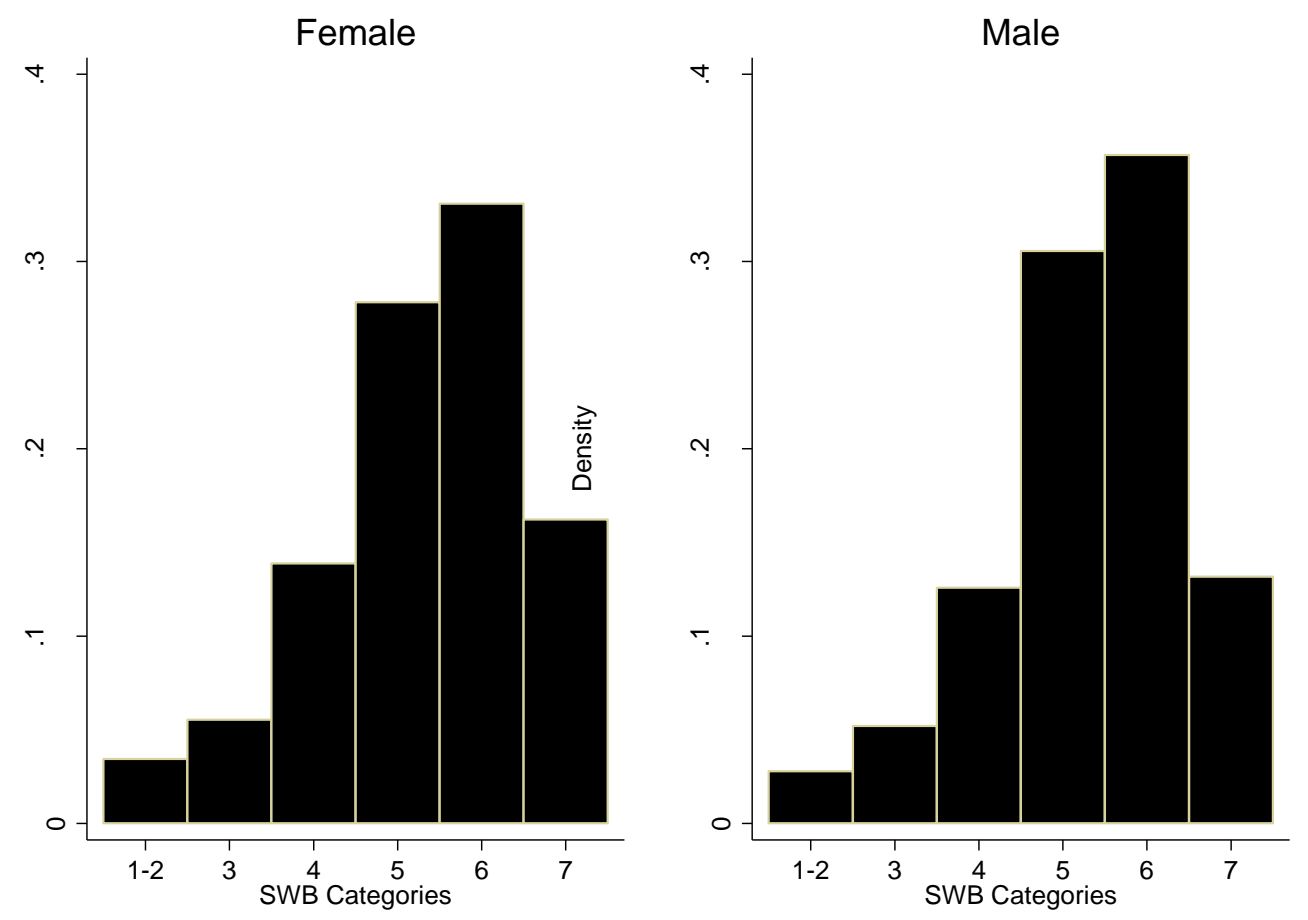
Fig. 2. A stylised graph of absolute and relative income effects for the low and high income group (relatively to the median class)

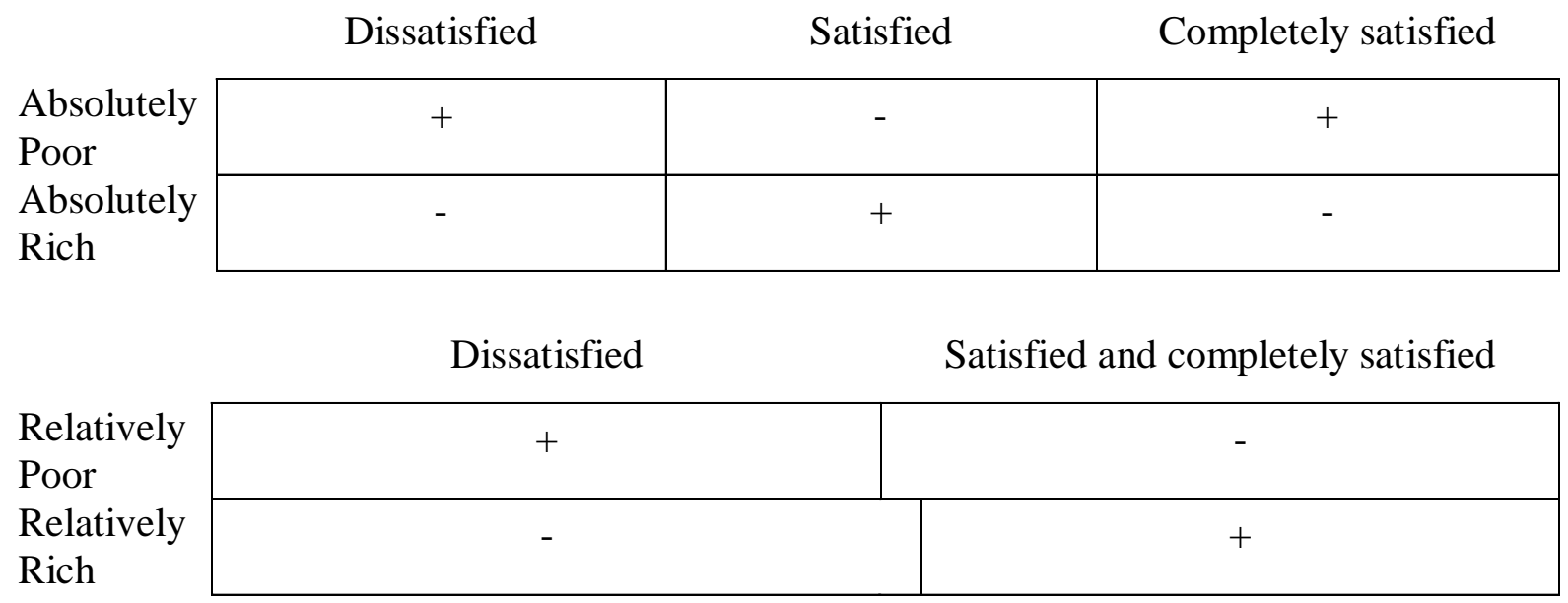

Note: a positive sign means that the income group in the row is more likely to belong to the column category (than the median income group). 
Table 1

Average SWB by gender and income groups

\begin{tabular}{|c|c|c|c|c|}
\hline $\begin{array}{l}\text { Absolute income } \\
\text { groups }\end{array}$ & Mean SWB & $\mathrm{N}$ & $\%$ & \\
\hline & \multicolumn{4}{|c|}{ Females } \\
\hline ai1 & 4 & 2297 & $8.5 \%$ & \\
\hline ai2 & 4.2 & 2463 & $9.1 \%$ & \\
\hline ai3 & 4.2 & 4951 & $18.4 \%$ & \\
\hline ai4 & 4.3 & 5395 & $20.0 \%$ & \\
\hline ai5 & 4.4 & 5832 & $21.6 \%$ & \\
\hline ai6 & 4.4 & 2896 & $10.7 \%$ & \\
\hline ai7 & 4.5 & 3112 & $11.5 \%$ & \\
\hline \multirow[t]{2}{*}{ Total } & 4.3 & 26946 & & $100 \%$ \\
\hline & \multicolumn{4}{|c|}{ Males } \\
\hline ai1 & 4 & 1530 & $6.5 \%$ & \\
\hline ai2 & 4 & 1880 & $7.9 \%$ & \\
\hline ai3 & 4 & 4231 & $17.8 \%$ & \\
\hline ai4 & 4 & 4863 & $20.5 \%$ & \\
\hline ai5 & 4 & 5405 & $22.8 \%$ & \\
\hline ai6 & 4 & 2833 & $11.9 \%$ & \\
\hline ai7 & 4 & 2970 & $12.5 \%$ & \\
\hline Total & 4 & 23712 & & $100 \%$ \\
\hline
\end{tabular}

Table 2

Descriptive statistics on equivalised income by gender and income classes

\begin{tabular}{|c|c|c|c|c|c|c|}
\hline $\begin{array}{l}\text { Absolute income } \\
\text { groups }\end{array}$ & Mean & Min & Max & $\mathrm{N}$ & & $\%$ \\
\hline & \multicolumn{6}{|c|}{ Females } \\
\hline ai1 & 4917 & 0 & 7504 & 2297 & $9 \%$ & \\
\hline ai2 & 9006 & 7506 & 10364 & 2463 & $9 \%$ & \\
\hline ai3 & 12863 & 10366 & 15371 & 4951 & $18 \%$ & \\
\hline ai4 & 18232 & 15372 & 21203 & 5395 & $20 \%$ & \\
\hline ai5 & 25336 & 21204 & 30320 & 5832 & $22 \%$ & \\
\hline ai6 & 34280 & 30326 & 39262 & 2896 & $11 \%$ & \\
\hline ai7 & 56011 & 39268 & 241070 & 3112 & $12 \%$ & \\
\hline \multirow[t]{2}{*}{ Total } & 22893 & 0 & 241070 & 26946 & & $100 \%$ \\
\hline & \multicolumn{6}{|c|}{ Males } \\
\hline ai1 & 4923 & 0 & 7504 & 1530 & $6 \%$ & \\
\hline ai2 & 9031 & 7506 & 10364 & 1880 & $8 \%$ & \\
\hline ai3 & 12922 & 10366 & 15370 & 4231 & $18 \%$ & \\
\hline ai4 & 18237 & 15372 & 21203 & 4863 & $21 \%$ & \\
\hline ai5 & 25358 & 21204 & 30320 & 5405 & $23 \%$ & \\
\hline ai6 & 34336 & 30331 & 39262 & 2833 & $12 \%$ & \\
\hline ai7 & 56142 & 39281 & 241070 & 2970 & $13 \%$ & \\
\hline Total & 23994 & 0 & 241070 & 23712 & & \\
\hline
\end{tabular}


Table 3

Distribution of "perceived financial situation"

\begin{tabular}{lccc}
\hline & $\begin{array}{c}\text { Variable } \\
\text { labels }\end{array}$ & $\mathrm{N}$ & $\%$ \\
\hline & \multicolumn{3}{c}{ Females } \\
\cline { 2 - 4 } finding it very difficult & fs1 & 547 & $2 \%$ \\
finding it quite difficult & fs2 & 1329 & $5 \%$ \\
just about getting by & fs3 & 6276 & $23 \%$ \\
doing alright & fs4 & 10309 & $38 \%$ \\
living comfortably & fs5 & 8485 & $31 \%$ \\
Total & & 26946 & \\
\hline & & & \\
finding it very difficult & Males & \\
finding it quite difficult & fs2 & 411 & $2 \%$ \\
just about getting by & fs3 & 1023 & 4711 \\
doing alright & fs4 & 8890 & $24 \%$ \\
living comfortably & fs5 & 7677 & $37 \%$ \\
Total & & 23712 & \\
\hline
\end{tabular}


Table 4

Correlation between income classes and perceived financial situation

\begin{tabular}{|c|c|c|c|c|c|c|c|c|c|c|c|c|}
\hline & \multicolumn{4}{|c|}{ Absolute income groups } & \multirow[b]{2}{*}{ ai5 } & \multirow[b]{2}{*}{ ai6 } & \multirow[b]{2}{*}{ ai7 } & \multicolumn{4}{|c|}{ Relative income groups } & \multirow[b]{2}{*}{ fs5 } \\
\hline & ail & ai2 & ai3 & ai4 & & & & fs1 & fs2 & fs3 & s4 & \\
\hline & & \multicolumn{11}{|c|}{ Females } \\
\hline \multicolumn{13}{|l|}{$\begin{array}{l}\text { Absolute } \\
\text { income groups }\end{array}$} \\
\hline ai1 & 1 & & & & & & & & & & & \\
\hline ai2 & -0.0968 & 1.0000 & & & & & & & & & & \\
\hline ai3 & -0.1448 & -0.1505 & 1.0000 & & & & & & & & & \\
\hline ai4 & -0.1527 & -0.1587 & -0.2374 & 1.0000 & & & & & & & & \\
\hline ai5 & -0.1604 & -0.1667 & -0.2493 & -0.2630 & 1.0000 & & & & & & & \\
\hline ai6 & -0.1059 & -0.1101 & -0.1646 & -0.1736 & -0.1824 & 1.0000 & & & & & & \\
\hline ai7 & -0.1103 & -0.1146 & -0.1714 & -0.1808 & -0.1899 & -0.1254 & 1.0000 & & & & & \\
\hline \multicolumn{13}{|l|}{$\begin{array}{l}\text { Relative } \\
\text { income groups }\end{array}$} \\
\hline fs 1 & 0.0927 & 0.0557 & 0.0166 & -0.0161 & -0.0431 & -0.0347 & -0.0421 & 1.0000 & & & & \\
\hline fs 2 & 0.0943 & 0.0669 & 0.0318 & -0.0249 & -0.0448 & -0.0348 & -0.0587 & -0.0328 & 1.0000 & & & \\
\hline fs 3 & 0.0994 & 0.1083 & 0.0773 & 0.0150 & -0.0730 & -0.0767 & -0.1285 & -0.0793 & -0.1255 & 1.0000 & & \\
\hline fs 4 & -0.0541 & -0.0462 & -0.0128 & 0.0445 & 0.0497 & 0.0151 & -0.0298 & -0.1133 & -0.1793 & -0.4338 & 1.0000 & \\
\hline fs 5 & -0.1060 & -0.0983 & -0.0768 & -0.0437 & 0.0484 & 0.0808 & 0.1883 & -0.0976 & -0.1544 & -0.3736 & -0.5337 & 1 \\
\hline
\end{tabular}


Table 4

continued

\begin{tabular}{|c|c|c|c|c|c|c|c|c|c|c|c|}
\hline & \multicolumn{6}{|c|}{ Absolute income groups } & \multicolumn{5}{|c|}{ Relative income groups } \\
\hline ai1 & ai2 & ai3 & ai4 & ai5 & ai6 & ai7 & fs1 1 & fs2 & fs3 & $\mathrm{s} 4$ & fs5 \\
\hline
\end{tabular}

\begin{tabular}{|c|c|c|c|c|c|c|c|c|c|c|c|c|}
\hline $\begin{array}{l}\text { Absolute } \\
\text { income groups }\end{array}$ & & & & & & & & & & & & \\
\hline ai1 & 1 & & & & & & & & & & & \\
\hline ai2 & -0.0771 & 1.0000 & & & & & & & & & & \\
\hline ai3 & -0.1224 & -0.1368 & 1.0000 & & & & & & & & & \\
\hline ai4 & -0.1334 & -0.1491 & -0.2367 & 1.0000 & & & & & & & & \\
\hline ai5 & -0.1427 & -0.1594 & -0.2532 & -0.2760 & 1.0000 & & & & & & & \\
\hline ai6 & -0.0967 & -0.1081 & -0.1717 & -0.1871 & -0.2002 & 1.0000 & & & & & & \\
\hline ai7 & -0.0994 & -0.1110 & -0.1763 & -0.1922 & -0.2056 & -0.1394 & 1.0000 & & & & & \\
\hline $\begin{array}{l}\text { Relative income } \\
\text { groups }\end{array}$ & & & & & & & & & & & & \\
\hline fs 1 & 0.0861 & 0.0507 & 0.0276 & -0.0074 & -0.0437 & -0.0360 & -0.0376 & 1.0000 & & & & \\
\hline $\mathrm{fs} 2$ & 0.0642 & 0.0506 & 0.0295 & -0.0061 & -0.0224 & -0.0360 & -0.0521 & -0.0282 & 1.0000 & & & \\
\hline fs 3 & 0.0793 & 0.1037 & 0.0950 & 0.0224 & -0.0665 & -0.0786 & -0.1196 & -0.0748 & -0.1196 & 1.0000 & & \\
\hline fs 4 & -0.0371 & -0.0428 & -0.0171 & 0.0356 & 0.0462 & 0.0204 & -0.0396 & -0.1029 & -0.1644 & -0.4362 & 1.0000 & \\
\hline fs 5 & -0.0860 & -0.0866 & -0.0896 & -0.0526 & 0.0348 & 0.0764 & 0.1834 & -0.0919 & -0.1469 & -0.3897 & -0.5359 & 1 \\
\hline
\end{tabular}

Note: Variable labels fs1, fs2, etc., are the first, the second, etc., of the relative income groups (see Table 3) 
Table 5

Discrete changes on probabilities for the generalised model without relative income (reference group: ai4)

\begin{tabular}{|c|c|c|c|c|c|c|}
\hline $\begin{array}{l}\begin{array}{l}\text { Income } \\
\text { groups }\end{array}\end{array}$ & $\mathrm{J}=1$ & $\mathrm{~J}=2$ & $\mathrm{~J}=3$ & $\mathrm{~J}=4$ & $\mathrm{~J}=5$ & $\mathrm{~J}=6$ \\
\hline & \multicolumn{6}{|c|}{ Females } \\
\hline \multirow[t]{2}{*}{ ai1 } & $0.0170 * *$ & $0.0145^{*}$ & $0.0191^{*}$ & $-0.0269 * *$ & $-0.0537 * * *$ & $0.0299 * *$ \\
\hline & $(0.0081)$ & $(0.0087)$ & $(0.011)$ & $(0.013)$ & $(0.014)$ & $(0.013)$ \\
\hline \multirow[t]{2}{*}{ ai2 } & $0.0190 * *$ & 0.00281 & 0.0173 & $-0.0398 * * *$ & $-0.0464 * * *$ & $0.0471 * * *$ \\
\hline & $(0.0083)$ & $(0.0085)$ & $(0.011)$ & $(0.013)$ & $(0.014)$ & (0.013) \\
\hline \multirow[t]{2}{*}{ ai3 } & $0.0115^{*}$ & 0.00611 & -0.000632 & 0.000646 & $-0.0420 * * *$ & $0.0243^{* *}$ \\
\hline & $(0.0064)$ & $(0.0069)$ & $(0.0089)$ & $(0.011)$ & $(0.011)$ & $(0.0096)$ \\
\hline \multirow[t]{2}{*}{ ai5 } & -0.00710 & -0.00392 & $-0.0149 *$ & 0.0130 & $0.0332 * * *$ & $-0.0203 * *$ \\
\hline & $(0.0060)$ & $(0.0066)$ & $(0.0085)$ & $(0.010)$ & $(0.011)$ & $(0.0089)$ \\
\hline \multirow[t]{2}{*}{ ai6 } & -0.00398 & -0.00956 & $-0.0218 * *$ & 0.0139 & $0.0542 * * *$ & $-0.0328 * * *$ \\
\hline & $(0.0075)$ & $(0.0080)$ & $(0.010)$ & $(0.012)$ & (0.014) & $(0.011)$ \\
\hline \multirow[t]{3}{*}{ ai7 } & $-0.0166^{* *}$ & -0.00566 & $-0.0335^{* * *}$ & $0.0243 *$ & $0.0640 * * *$ & $-0.0326 * * *$ \\
\hline & $(0.0076)$ & $(0.0085)$ & $(0.010)$ & $(0.013)$ & $(0.013)$ & $(0.012)$ \\
\hline & \multicolumn{6}{|c|}{ Males } \\
\hline \multirow[t]{2}{*}{ ai1 } & 0.0194* & 0.0163 & -0.0108 & -0.0224 & $-0.0562 * * *$ & $0.0536 * * *$ \\
\hline & $(0.010)$ & $(0.011)$ & (0.013) & $(0.016)$ & $(0.017)$ & $(0.016)$ \\
\hline \multirow[t]{2}{*}{ ai2 } & $0.0170 *$ & 0.0158 & $0.0229 *$ & $-0.0334 * *$ & $-0.0832 * * *$ & $0.0610 * * *$ \\
\hline & $(0.0096)$ & $(0.010)$ & $(0.013)$ & $(0.015)$ & (0.016) & $(0.015)$ \\
\hline \multirow[t]{2}{*}{ ai3 } & 0.00922 & $0.0133 *$ & 0.00695 & $-0.0251 * *$ & $-0.0278 * *$ & $0.0234 * *$ \\
\hline & $(0.0069)$ & $(0.0076)$ & $(0.0096)$ & $(0.012)$ & $(0.012)$ & $(0.010)$ \\
\hline \multirow[t]{2}{*}{ ai5 } & $-0.0106^{*}$ & 0.0000791 & 0.0000627 & 0.0135 & $0.0256^{* *}$ & $-0.0286^{* * *}$ \\
\hline & $(0.0064)$ & $(0.0072)$ & $(0.0091)$ & $(0.011)$ & $(0.012)$ & $(0.0092)$ \\
\hline \multirow[t]{2}{*}{ ai6 } & -0.00991 & -0.00936 & $-0.0219 * *$ & 0.0210 & $0.0618 * * *$ & $-0.0416 * * *$ \\
\hline & $(0.0079)$ & $(0.0084)$ & $(0.011)$ & (0.014) & $(0.015)$ & $(0.011)$ \\
\hline \multirow[t]{2}{*}{ ai7 } & -0.0130 & -0.0080 & $-0.0341 * * *$ & $0.0306 * * *$ & $0.0737 * * *$ & $-0.0491 * * *$ \\
\hline & $(0.0083)$ & $(0.0094)$ & $(0.0127)$ & $(0.0154)$ & $(0.0156)$ & $(0.0142)$ \\
\hline
\end{tabular}

Note: Standard errors in parentheses, ${ }^{* * *} \mathrm{p}<0.01,{ }^{* *} \mathrm{p}<0.05,{ }^{*} \mathrm{p}<0.1$ 
Table 6

Discrete changes on probabilities for the generalised models with absolute and relative income (reference groups ai4 and fs3)

\begin{tabular}{|c|c|c|c|c|c|c|}
\hline $\begin{array}{l}\text { Income } \\
\text { groups }\end{array}$ & $\mathrm{J}=1$ & $\mathrm{~J}=2$ & $\mathrm{~J}=3$ & $\mathrm{~J}=4$ & $\mathrm{~J}=5$ & $\mathrm{~J}=6$ \\
\hline & \multicolumn{6}{|c|}{ Females } \\
\hline ai1 & $\begin{array}{l}0.0113 \\
(0.0089)\end{array}$ & $\begin{array}{l}0.0111 \\
(0.0099)\end{array}$ & $\begin{array}{l}-0.0119 \\
(0.013)\end{array}$ & $\begin{array}{l}-0.0165 \\
(0.017)\end{array}$ & $\begin{array}{l}-0.0424 * * \\
(0.017)\end{array}$ & $\begin{array}{l}0.0485 * * * \\
(0.015)\end{array}$ \\
\hline ai2 & $\begin{array}{l}0.0106 \\
(0.0085)\end{array}$ & $\begin{array}{l}0.0124 \\
(0.0095)\end{array}$ & $\begin{array}{l}0.0213^{*} \\
(0.013)\end{array}$ & $\begin{array}{l}-0.0308 * * \\
(0.015)\end{array}$ & $\begin{array}{l}-0.0711 * * * \\
(0.016)\end{array}$ & $\begin{array}{l}0.0576 * * * \\
(0.014)\end{array}$ \\
\hline ai3 & $\begin{array}{l}0.00596 \\
(0.0062)\end{array}$ & $\begin{array}{l}0.0112 \\
(0.0071)\end{array}$ & $\begin{array}{l}0.00644 \\
(0.0094)\end{array}$ & $\begin{array}{l}-0.0251 * * \\
(0.012)\end{array}$ & $\begin{array}{l}-0.0217 * \\
(0.012)\end{array}$ & $\begin{array}{l}0.0232 * * \\
(0.010)\end{array}$ \\
\hline ai5 & $\begin{array}{l}-0.00968 * \\
(0.0058)\end{array}$ & $\begin{array}{l}0.00153 \\
(0.0068)\end{array}$ & $\begin{array}{l}0.00173 \\
(0.0090)\end{array}$ & $\begin{array}{l}0.0132 \\
(0.011)\end{array}$ & $\begin{array}{l}0.0205^{*} \\
(0.012)\end{array}$ & $\begin{array}{l}-0.0272 * * * \\
(0.0090)\end{array}$ \\
\hline ai6 & $\begin{array}{l}-0.00747 \\
(0.0072)\end{array}$ & $\begin{array}{l}-0.00664 \\
(0.0080)\end{array}$ & $\begin{array}{l}-0.0197 * \\
(0.011)\end{array}$ & $\begin{array}{l}0.0214 \\
(0.014)\end{array}$ & $\begin{array}{l}0.0520 * * * \\
(0.015)\end{array}$ & $\begin{array}{l}-0.0396^{* * * *} \\
(0.011)\end{array}$ \\
\hline ai7 & $\begin{array}{l}-0.0115 \\
(0.0073)\end{array}$ & $\begin{array}{l}-0.00492 \\
(0.0083)\end{array}$ & $\begin{array}{l}-0.0313^{* * * *} \\
(0.011)\end{array}$ & $\begin{array}{l}0.0333^{* *} \\
(0.014)\end{array}$ & $\begin{array}{l}0.0612 * * * \\
(0.015)\end{array}$ & $\begin{array}{l}-0.0468 * * * \\
(0.012)\end{array}$ \\
\hline fs 1 & $\begin{array}{l}0.0845^{* * * *} \\
(0.017)\end{array}$ & $\begin{array}{l}0.0484 * * * \\
(0.019)\end{array}$ & $\begin{array}{l}0.00379 \\
(0.023)\end{array}$ & $\begin{array}{l}-0.0690 * * \\
(0.028)\end{array}$ & $\begin{array}{l}-0.0816 * * * \\
(0.031)\end{array}$ & $\begin{array}{l}0.0139 \\
(0.029)\end{array}$ \\
\hline fs2 & $\begin{array}{l}0.0293 * * * \\
(0.0097)\end{array}$ & $\begin{array}{l}0.0224 * * \\
(0.011)\end{array}$ & $\begin{array}{l}0.0213 \\
(0.015)\end{array}$ & $\begin{array}{l}-0.0134 \\
(0.019)\end{array}$ & $\begin{array}{l}-0.0555^{* * *} \\
(0.019)\end{array}$ & $\begin{array}{l}-0.00417 \\
(0.016)\end{array}$ \\
\hline fs 4 & $\begin{array}{l}-0.0158 * * * \\
(0.0049)\end{array}$ & $\begin{array}{l}-0.0227 * * * \\
(0.0058)\end{array}$ & $\begin{array}{l}-0.0300 * * * \\
(0.0075)\end{array}$ & $\begin{array}{l}0.00910 \\
(0.0096)\end{array}$ & $\begin{array}{l}0.0558^{* * * *} \\
(0.010)\end{array}$ & $\begin{array}{l}0.00353 \\
(0.0081)\end{array}$ \\
\hline fs 5 & $\begin{array}{l}-0.0142 * * \\
(0.0059)\end{array}$ & $\begin{array}{l}-0.0309 * * * \\
(0.0065)\end{array}$ & $\begin{array}{l}-0.0449 * * * \\
(0.0084)\end{array}$ & $\begin{array}{l}-0.0248^{* * *} \\
(0.011)\end{array}$ & $\begin{array}{l}0.0866^{* * * *} \\
(0.011)\end{array}$ & $\begin{array}{l}0.0282^{* * * *} \\
(0.0091)\end{array}$ \\
\hline & \multicolumn{6}{|c|}{ Males } \\
\hline ai1 & $\begin{array}{l}0.0103 \\
(0.0074)\end{array}$ & $\begin{array}{l}0.0102 \\
(0.0083)\end{array}$ & $\begin{array}{l}0.0197 * \\
(0.011)\end{array}$ & $\begin{array}{l}-0.0214 \\
(0.013)\end{array}$ & $\begin{array}{l}-0.0437 * * * \\
(0.014)\end{array}$ & $\begin{array}{l}0.0248^{*} \\
(0.013)\end{array}$ \\
\hline ai2 & $\begin{array}{l}0.0137^{*} \\
(0.0076)\end{array}$ & $\begin{array}{l}-0.00193 \\
(0.0080)\end{array}$ & $\begin{array}{l}0.0156 \\
(0.011)\end{array}$ & $\begin{array}{l}-0.0371^{* * * *} \\
(0.013)\end{array}$ & $\begin{array}{l}-0.0355^{* *} \\
(0.014)\end{array}$ & $\begin{array}{l}0.0452^{* * * *} \\
(0.013)\end{array}$ \\
\hline ai3 & $\begin{array}{l}0.00939 \\
(0.0059)\end{array}$ & $\begin{array}{l}0.00457 \\
(0.0066)\end{array}$ & $\begin{array}{l}-0.000827 \\
(0.0089)\end{array}$ & $\begin{array}{l}0.00194 \\
(0.011)\end{array}$ & $\begin{array}{l}-0.0384 * * * \\
(0.011)\end{array}$ & $\begin{array}{l}0.0233 * * \\
(0.0095)\end{array}$ \\
\hline ai5 & $\begin{array}{l}-0.00592 \\
(0.0055)\end{array}$ & $\begin{array}{l}-0.00295 \\
(0.0064)\end{array}$ & $\begin{array}{l}-0.0137 \\
(0.0085)\end{array}$ & $\begin{array}{l}0.0134 \\
(0.010)\end{array}$ & $\begin{array}{l}0.0306 * * * \\
(0.011)\end{array}$ & $\begin{array}{l}-0.0214 * * \\
(0.0087)\end{array}$ \\
\hline ai6 & $\begin{array}{l}-0.00266 \\
(0.0070)\end{array}$ & $\begin{array}{l}-0.00853 \\
(0.0076)\end{array}$ & $\begin{array}{l}-0.0199 * \\
(0.010)\end{array}$ & $\begin{array}{l}0.0155 \\
(0.013)\end{array}$ & $\begin{array}{l}0.0495^{* * * *} \\
(0.014)\end{array}$ & $\begin{array}{l}-0.0339 * * * \\
(0.011)\end{array}$ \\
\hline ai7 & $\begin{array}{l}-0.0159 * * \\
(0.0070)\end{array}$ & $\begin{array}{l}-0.00197 \\
(0.0083)\end{array}$ & $\begin{array}{l}-0.0291 * * * \\
(0.010)\end{array}$ & $\begin{array}{l}0.0272 * * \\
(0.013)\end{array}$ & $\begin{array}{l}0.0552 * * * \\
(0.014)\end{array}$ & $\begin{array}{l}-0.0355^{* * *} \\
(0.011)\end{array}$ \\
\hline fs 1 & $\begin{array}{l}0.0764 * * * \\
(0.015)\end{array}$ & $\begin{array}{l}0.0377 * * \\
(0.015)\end{array}$ & $\begin{array}{l}0.00906 \\
(0.020)\end{array}$ & $\begin{array}{l}-0.0254 \\
(0.025)\end{array}$ & $\begin{array}{l}-0.0817 * * * \\
(0.026)\end{array}$ & $\begin{array}{l}-0.0161 \\
(0.025)\end{array}$ \\
\hline fs2 & $\begin{array}{l}0.0322 * * * \\
(0.0087)\end{array}$ & $\begin{array}{l}0.0205^{* *} \\
(0.0098)\end{array}$ & $\begin{array}{l}0.0188 \\
(0.013)\end{array}$ & $\begin{array}{l}-0.0131 \\
(0.016)\end{array}$ & $\begin{array}{l}-0.0454 * * * \\
(0.017)\end{array}$ & $\begin{array}{l}-0.0129 \\
(0.015)\end{array}$ \\
\hline fs 4 & $\begin{array}{l}-0.0168 * * * \\
(0.0046)\end{array}$ & $\begin{array}{l}-0.0232 * * * \\
(0.0054)\end{array}$ & $\begin{array}{l}-0.0256^{* * * *} \\
(0.0072)\end{array}$ & $\begin{array}{l}0.00248 \\
(0.0086)\end{array}$ & $\begin{array}{l}0.0568 * * * \\
(0.0091)\end{array}$ & $\begin{array}{l}0.00636 \\
(0.0078)\end{array}$ \\
\hline fs 5 & $\begin{array}{l}-0.0141 * * \\
(0.0056)\end{array}$ & $\begin{array}{l}-0.0312^{* * * *} \\
(0.0061)\end{array}$ & $\begin{array}{l}-0.0461 * * * \\
(0.0080)\end{array}$ & $\begin{array}{l}-0.0235^{* *} \\
(0.0095)\end{array}$ & $\begin{array}{l}0.0641 * * * \\
(0.0099)\end{array}$ & $\begin{array}{l}0.0508 * * * \\
(0.0090)\end{array}$ \\
\hline
\end{tabular}

Note: Standard errors in parentheses, ${ }^{* * *} \mathrm{p}<0.01,{ }^{* *} \mathrm{p}<0.05,{ }^{*} \mathrm{p}<0.1$ 


\section{Appendix A}

Table A1

Coefficients estimate after the random effects generalized ordered probit for females

\begin{tabular}{|c|c|c|c|c|c|}
\hline \multirow[b]{2}{*}{ Income groups } & \multicolumn{5}{|c|}{ Subjective well-being levels } \\
\hline & $\mathrm{J}=1$ & $\mathrm{~J}=2$ & $\mathrm{~J}=3$ & $\mathrm{~J}=4$ & $\mathrm{~J}=5$ \\
\hline \multirow[t]{2}{*}{ ai1 } & $-0.231 * * *$ & $-0.252 * * *$ & $-0.262 * * *$ & $-0.105^{* *}$ & $0.181 * * *$ \\
\hline & $(0.076)$ & $(0.058)$ & $(0.048)$ & $(0.046)$ & $(0.056)$ \\
\hline \multirow[t]{2}{*}{ ai2 } & $-0.252 * * *$ & $-0.176^{* * *}$ & $-0.203 * * *$ & 0.00301 & $0.278 * * *$ \\
\hline & $(0.075)$ & $(0.058)$ & $(0.047)$ & $(0.045)$ & $(0.052)$ \\
\hline \multirow[t]{2}{*}{ ai3 } & $-0.161 * *$ & $-0.146^{* * * *}$ & $-0.0903 * *$ & $-0.0783 * *$ & $0.149 * * *$ \\
\hline & $(0.063)$ & $(0.047)$ & $(0.037)$ & $(0.034)$ & $(0.041)$ \\
\hline \multirow[t]{2}{*}{ ai5 } & $0.112 *$ & $0.0987 * *$ & $0.144 * * *$ & $0.0572 *$ & $-0.133 * * *$ \\
\hline & $(0.067)$ & $(0.048)$ & $(0.037)$ & $(0.033)$ & $(0.041)$ \\
\hline \multirow[t]{2}{*}{ ai6 } & 0.0615 & $0.122 * *$ & $0.198 * * *$ & $0.0953 * *$ & $-0.218 * * *$ \\
\hline & $(0.082)$ & $(0.061)$ & $(0.047)$ & $(0.042)$ & $(0.053)$ \\
\hline \multirow[t]{2}{*}{ ai7 } & $0.282 * * *$ & $0.206^{* * *}$ & $0.320 * * *$ & $0.140 * * *$ & $-0.217 * * *$ \\
\hline & $(0.096)$ & $(0.066)$ & $(0.052)$ & $(0.046)$ & $(0.055)$ \\
\hline \multirow[t]{2}{*}{ Lag-SAH } & $0.0546 * *$ & $0.0546^{* *}$ & $0.0546^{* *}$ & $0.0546 * *$ & $0.0546 * *$ \\
\hline & $(0.023)$ & $(0.023)$ & $(0.023)$ & $(0.023)$ & $(0.023)$ \\
\hline \multirow[t]{2}{*}{ Age } & $-0.0149 * * *$ & $-0.0149 * * *$ & $-0.0149 * * *$ & $-0.0149 * * *$ & $-0.0149 * * *$ \\
\hline & $(0.0034)$ & $(0.0034)$ & $(0.0034)$ & $(0.0034)$ & $(0.0034)$ \\
\hline \multirow[t]{2}{*}{ educ2 } & 0.0287 & 0.0287 & 0.0287 & 0.0287 & 0.0287 \\
\hline & $(0.087)$ & $(0.087)$ & $(0.087)$ & $(0.087)$ & $(0.087)$ \\
\hline \multirow[t]{2}{*}{ educ3 } & -0.153 & -0.153 & -0.153 & -0.153 & -0.153 \\
\hline & $(0.10)$ & $(0.10)$ & $(0.10)$ & $(0.10)$ & $(0.10)$ \\
\hline \multirow[t]{2}{*}{ educ4 } & $-0.377 * *$ & $-0.377 * *$ & $-0.377 * *$ & $-0.377 * *$ & $-0.377 * *$ \\
\hline & $(0.18)$ & $(0.18)$ & $(0.18)$ & $(0.18)$ & $(0.18)$ \\
\hline \multirow[t]{2}{*}{ married } & $0.151 * *$ & $0.151 * *$ & $0.151 * *$ & $0.151 * *$ & $0.151 * *$ \\
\hline & $(0.060)$ & $(0.060)$ & $(0.060)$ & $(0.060)$ & $(0.060)$ \\
\hline \multirow[t]{2}{*}{ divsep } & $-0.208 * *$ & $-0.208 * *$ & $-0.208 * *$ & $-0.208 * *$ & $-0.208 * *$ \\
\hline & $(0.089)$ & $(0.089)$ & $(0.089)$ & $(0.089)$ & $(0.089)$ \\
\hline \multirow[t]{2}{*}{ widowed } & $-0.286^{*}$ & $-0.286^{*}$ & $-0.286^{*}$ & $-0.286^{*}$ & $-0.286^{*}$ \\
\hline & $(0.15)$ & $(0.15)$ & $(0.15)$ & $(0.15)$ & $(0.15)$ \\
\hline \multirow{2}{*}{$\begin{array}{l}\text { Lag- } \\
\text { unemployed }\end{array}$} & -0.0106 & -0.0106 & -0.0106 & -0.0106 & -0.0106 \\
\hline & $(0.028)$ & $(0.028)$ & $(0.028)$ & $(0.028)$ & $(0.028)$ \\
\hline \# of kids & $0.0498 * *$ & $0.0498 * *$ & $0.0498 * *$ & $0.0498 * *$ & $0.0498 * *$ \\
\hline
\end{tabular}




\begin{tabular}{llllll} 
& $(0.022)$ & $(0.022)$ & $(0.022)$ & $(0.022)$ & $(0.022)$ \\
household size & $-0.0645^{* * *}$ & $-0.0645^{* * *}$ & $-0.0645^{* * *}$ & $-0.0645^{* * *}$ & $-0.0645 * * *$ \\
& $(0.018)$ & $(0.018)$ & $(0.018)$ & $(0.018)$ & $(0.018)$ \\
\multirow{2}{*}{ Constant } & $0.978^{* * *}$ & $0.262^{*}$ & $-0.677^{* * *}$ & $-1.817 * * *$ & $-3.274 * * *$ \\
& $(0.15)$ & $(0.15)$ & $(0.15)$ & $(0.15)$ & $(0.15)$ \\
\multirow{2}{*}{ Obs } & 26966 & 26966 & 26966 & 26966 & 26966 \\
Log- L & -37160 & & & & \\
\hline
\end{tabular}

Standard errors in parentheses; $* * * \mathrm{p}<0.01, * * \mathrm{p}<0.05, * \mathrm{p}<0.1$

Note: coefficients on time dummies and regional dummies not reported 
Table A2

Coefficients estimate after the random effects generalized ordered probit for males

\begin{tabular}{|c|c|c|c|c|c|}
\hline \multirow[b]{2}{*}{ Income groups } & \multicolumn{5}{|c|}{ Subjective well-being levels } \\
\hline & $\mathrm{J}=1$ & $\mathrm{~J}=2$ & $\mathrm{~J}=3$ & $\mathrm{~J}=4$ & $\mathrm{~J}=5$ \\
\hline \multirow[t]{2}{*}{ ai1 } & $-0.281 * * *$ & $-0.306^{* * * *}$ & $-0.143^{* *}$ & -0.0119 & $0.352 * * *$ \\
\hline & $(0.093)$ & $(0.071)$ & $(0.059)$ & $(0.055)$ & $(0.066)$ \\
\hline \multirow[t]{2}{*}{ ai2 } & $-0.246 * * *$ & $-0.280 * * *$ & $-0.310 * * *$ & $-0.104 * *$ & $0.392 * * *$ \\
\hline & $(0.090)$ & $(0.067)$ & $(0.055)$ & $(0.052)$ & $(0.062)$ \\
\hline \multirow[t]{2}{*}{ ai3 } & $-0.141 * *$ & $-0.199 * * *$ & $-0.168 * * *$ & -0.0205 & $0.161 * * *$ \\
\hline & $(0.072)$ & $(0.052)$ & $(0.041)$ & $(0.037)$ & $(0.047)$ \\
\hline \multirow[t]{2}{*}{ ai5 } & $0.188 * *$ & $0.103 *$ & 0.0625 & -0.0142 & $-0.215 * * *$ \\
\hline & $(0.077)$ & $(0.053)$ & $(0.040)$ & $(0.035)$ & $(0.047)$ \\
\hline \multirow[t]{2}{*}{ ai6 } & $0.174 *$ & $0.193^{* * *}$ & $0.255^{* * *}$ & $0.0941 * *$ & $-0.322 * * *$ \\
\hline & $(0.096)$ & $(0.068)$ & $(0.052)$ & $(0.045)$ & $(0.061)$ \\
\hline \multirow[t]{2}{*}{ ai7 } & $0.234 * *$ & $0.213^{* * *}$ & $0.348 * * *$ & $0.115^{* *}$ & $-0.387 * * *$ \\
\hline & $(0.10)$ & $(0.072)$ & $(0.057)$ & $(0.050)$ & $(0.065)$ \\
\hline \multirow[t]{2}{*}{ Lag-SAH } & $0.104 * * *$ & $0.104 * * *$ & $0.104 * * *$ & $0.104 * * *$ & $0.104 * * *$ \\
\hline & $(0.026)$ & $(0.026)$ & $(0.026)$ & $(0.026)$ & $(0.026)$ \\
\hline \multirow[t]{2}{*}{ Age } & $-0.0186 * * *$ & $-0.0186 * * *$ & $-0.0186 * * *$ & $-0.0186 * * *$ & $-0.0186 * * *$ \\
\hline & $(0.0037)$ & $(0.0037)$ & $(0.0037)$ & $(0.0037)$ & $(0.0037)$ \\
\hline \multirow[t]{2}{*}{ educ2 } & 0.115 & 0.115 & 0.115 & 0.115 & 0.115 \\
\hline & $(0.11)$ & $(0.11)$ & $(0.11)$ & $(0.11)$ & $(0.11)$ \\
\hline \multirow[t]{2}{*}{ educ3 } & 0.145 & 0.145 & 0.145 & 0.145 & 0.145 \\
\hline & $(0.13)$ & $(0.13)$ & $(0.13)$ & $(0.13)$ & $(0.13)$ \\
\hline \multirow[t]{2}{*}{ educ4 } & -0.161 & -0.161 & -0.161 & -0.161 & -0.161 \\
\hline & $(0.23)$ & $(0.23)$ & $(0.23)$ & $(0.23)$ & $(0.23)$ \\
\hline \multirow[t]{2}{*}{ married } & 0.0292 & 0.0292 & 0.0292 & 0.0292 & 0.0292 \\
\hline & $(0.070)$ & $(0.070)$ & $(0.070)$ & $(0.070)$ & $(0.070)$ \\
\hline \multirow[t]{2}{*}{ divsep } & $-0.571 * * *$ & $-0.571 * * *$ & $-0.571 * * *$ & $-0.571 * * *$ & $-0.571 * * *$ \\
\hline & $(0.14)$ & $(0.14)$ & $(0.14)$ & $(0.14)$ & $(0.14)$ \\
\hline \multirow[t]{2}{*}{ widowed } & 0.0499 & 0.0499 & 0.0499 & 0.0499 & 0.0499 \\
\hline & $(0.24)$ & $(0.24)$ & $(0.24)$ & $(0.24)$ & $(0.24)$ \\
\hline \multicolumn{6}{|l|}{ Lag- } \\
\hline \multirow[t]{2}{*}{ unemployed } & $0.0739 * *$ & $0.0739 * *$ & $0.0739 * *$ & $0.0739 * *$ & $0.0739 * *$ \\
\hline & $(0.036)$ & $(0.036)$ & $(0.036)$ & $(0.036)$ & $(0.036)$ \\
\hline \multirow[t]{2}{*}{ \# of kids } & 0.0371 & 0.0371 & 0.0371 & 0.0371 & 0.0371 \\
\hline & $(0.025)$ & $(0.025)$ & $(0.025)$ & $(0.025)$ & $(0.025)$ \\
\hline
\end{tabular}




$\begin{array}{llllll}\text { household size } & -0.0430^{* *} & -0.0430^{* *} & -0.0430^{* *} & -0.0430^{* *} & -0.0430^{* *} \\ & (0.021) & (0.021) & (0.021) & (0.021) & (0.021) \\ \text { Constant } & 0.869 * * * & 0.135 & -0.802^{* * *} & -2.115^{* * *} & -3.783 * * * \\ & (0.17) & (0.17) & (0.17) & (0.17) & (0.17) \\ \text { Obs } & 23732 & 23732 & 23732 & 23732 & 23732 \\ \text { Log-L } & -31155 & & & & \end{array}$

Standard errors in parentheses; $* * * \mathrm{p}<0.01,{ }^{* *} \mathrm{p}<0.05,{ }^{*} \mathrm{p}<0.1$

Note: coefficients on time dummies and regional dummies not reported 
Table A3

Coefficients estimate after the random effects generalized ordered probit female, absolute and relative income dummies

\begin{tabular}{|c|c|c|c|c|c|}
\hline \multirow[b]{2}{*}{ Income groups } & \multicolumn{5}{|c|}{ Subjective well-being levels } \\
\hline & $\mathrm{J}=1$ & $\mathrm{~J}=2$ & $\mathrm{~J}=3$ & $\mathrm{~J}=4$ & $\mathrm{~J}=5$ \\
\hline \multirow[t]{2}{*}{ ai1 } & $-0.154 * *$ & $-0.172 * * *$ & $-0.206 * * *$ & $-0.0809 *$ & $0.149 * * *$ \\
\hline & $(0.078)$ & $(0.060)$ & $(0.049)$ & $(0.047)$ & $(0.056)$ \\
\hline \multirow[t]{2}{*}{ ai2 } & $-0.198 * * *$ & $-0.100^{*}$ & $-0.141 * * *$ & 0.0416 & $0.263 * * *$ \\
\hline & $(0.076)$ & $(0.059)$ & $(0.048)$ & $(0.045)$ & $(0.053)$ \\
\hline \multirow[t]{2}{*}{ ai3 } & $-0.141 * *$ & $-0.119 * *$ & $-0.0688 *$ & $-0.0645^{*}$ & $0.140 * * *$ \\
\hline & $(0.064)$ & $(0.048)$ & $(0.038)$ & $(0.035)$ & $(0.041)$ \\
\hline \multirow[t]{2}{*}{ ai5 } & 0.0996 & $0.0813^{*}$ & $0.123 * * *$ & 0.0393 & $-0.138 * * *$ \\
\hline & $(0.068)$ & $(0.048)$ & $(0.037)$ & $(0.033)$ & $(0.041)$ \\
\hline \multirow[t]{2}{*}{ ai6 } & 0.0435 & $0.103 *$ & $0.171 * * *$ & 0.0667 & $-0.224 * * *$ \\
\hline & $(0.083)$ & $(0.061)$ & $(0.048)$ & $(0.043)$ & $(0.053)$ \\
\hline \multirow[t]{2}{*}{ ai7 } & $0.293 * * *$ & $0.169 * *$ & $0.262 * * *$ & $0.0842 *$ & $-0.235 * * *$ \\
\hline & $(0.099)$ & $(0.067)$ & $(0.053)$ & $(0.047)$ & $(0.056)$ \\
\hline \multirow[t]{2}{*}{ fs 1} & $-0.776 * * *$ & $-0.715^{* * *} *$ & $-0.564 * * *$ & $-0.436 * * *$ & -0.110 \\
\hline & $(0.089)$ & $(0.079)$ & $(0.079)$ & $(0.093)$ & $(0.13)$ \\
\hline \multirow[t]{2}{*}{ fs 2} & $-0.385^{* * *}$ & $-0.362 * * *$ & $-0.335 * * *$ & $-0.256^{* * *}$ & -0.0882 \\
\hline & $(0.068)$ & $(0.055)$ & $(0.050)$ & $(0.055)$ & $(0.076)$ \\
\hline \multirow[t]{2}{*}{ fs 4} & $0.270 * * *$ & $0.344 * * *$ & $0.342 * * *$ & $0.271 * * *$ & 0.0418 \\
\hline & $(0.053)$ & $(0.038)$ & $(0.030)$ & $(0.029)$ & $(0.037)$ \\
\hline \multirow[t]{2}{*}{ fs 5} & $0.221 * * *$ & $0.396 * * *$ & $0.490 * * *$ & $0.493 * * *$ & $0.312 * * *$ \\
\hline & $(0.065)$ & $(0.047)$ & $(0.037)$ & $(0.034)$ & $(0.041)$ \\
\hline \multirow[t]{2}{*}{ Lag-SAH } & $0.0539 * *$ & $0.0539 * *$ & $0.0539 * *$ & $0.0539 * *$ & $0.0539 * *$ \\
\hline & $(0.023)$ & $(0.023)$ & $(0.023)$ & $(0.023)$ & $(0.023)$ \\
\hline \multirow[t]{2}{*}{ Age } & $-0.0484 * * *$ & $-0.0484 * * *$ & $-0.0484 * * *$ & $-0.0484 * * *$ & $-0.0484 * * *$ \\
\hline & $(0.0080)$ & $(0.0080)$ & $(0.0080)$ & $(0.0080)$ & $(0.0080)$ \\
\hline \multirow[t]{2}{*}{ educ2 } & 0.0160 & 0.0160 & 0.0160 & 0.0160 & 0.0160 \\
\hline & $(0.087)$ & $(0.087)$ & $(0.087)$ & $(0.087)$ & $(0.087)$ \\
\hline \multirow[t]{2}{*}{ educ3 } & -0.139 & -0.139 & -0.139 & -0.139 & -0.139 \\
\hline & $(0.10)$ & $(0.10)$ & $(0.10)$ & $(0.10)$ & $(0.10)$ \\
\hline \multirow[t]{2}{*}{ educ4 } & -0.261 & -0.261 & -0.261 & -0.261 & -0.261 \\
\hline & $(0.19)$ & $(0.19)$ & $(0.19)$ & $(0.19)$ & $(0.19)$ \\
\hline \multirow[t]{2}{*}{ married } & $0.132 * *$ & $0.132 * *$ & $0.132 * *$ & $0.132 * *$ & $0.132 * *$ \\
\hline & $(0.060)$ & $(0.060)$ & $(0.060)$ & $(0.060)$ & $(0.060)$ \\
\hline divsep & -0.134 & -0.134 & -0.134 & -0.134 & -0.134 \\
\hline
\end{tabular}




$\begin{array}{llllll} & (0.089) & (0.089) & (0.089) & (0.089) & (0.089) \\ \text { widowed } & -0.229 & -0.229 & -0.229 & -0.229 & -0.229 \\ & (0.15) & (0.15) & (0.15) & (0.15) & (0.15) \\ \text { Lag- } & & & & & \\ \text { unemployed } & 0.00738 & 0.00738 & 0.00738 & 0.00738 & 0.00738 \\ & (0.028) & (0.028) & (0.028) & (0.028) & (0.028) \\ \text { \# of kids } & 0.0593^{* * *} & 0.0593^{* * *} & 0.0593^{* * *} & 0.0593^{* * * *} & 0.0593 * * * \\ & (0.022) & (0.022) & (0.022) & (0.022) & (0.022) \\ \text { household size } & -0.0655^{* * *} & -0.0655^{* * * *} & -0.0655^{* * *} & -0.0655^{* * *} & -0.0655^{* * *} \\ & (0.018) & (0.018) & (0.018) & (0.018) & (0.018) \\ \text { Constant } & 1.215 * * * & 0.419 * * * & -0.560^{* * *} & -1.691 * * * & -3.007 * * * \\ & (0.16) & (0.15) & (0.15) & (0.15) & (0.15) \\ \text { Obs } & 26946 & 26946 & 26946 & 26946 & 26946 \\ \text { Log-L } & -36434 & & & & \end{array}$

Standard errors in parentheses; $* * * \mathrm{p}<0.01, * * \mathrm{p}<0.05,{ }^{*} \mathrm{p}<0.1$

Note: coefficients on time dummies and regional dummies not reported 
Table A4

Coefficients estimate after the random effects generalized ordered probit male, absolute and relative income dummies

\begin{tabular}{|c|c|c|c|c|c|}
\hline \multirow[b]{2}{*}{ Income groups } & \multicolumn{5}{|c|}{ Subjective well-being levels } \\
\hline & $\mathrm{J}=1$ & $\mathrm{~J}=2$ & $\mathrm{~J}=3$ & $\mathrm{~J}=4$ & $\mathrm{~J}=5$ \\
\hline \multirow[t]{2}{*}{ ai1 } & $-0.183^{*}$ & $-0.205^{* * *}$ & -0.0602 & 0.0271 & $0.315 * * *$ \\
\hline & $(0.097)$ & $(0.073)$ & $(0.060)$ & $(0.056)$ & $(0.067)$ \\
\hline \multirow[t]{2}{*}{ ai2 } & $-0.171 *$ & $-0.208 * * *$ & $-0.245 * * *$ & -0.0603 & $0.367 * * *$ \\
\hline & $(0.092)$ & $(0.068)$ & $(0.056)$ & $(0.052)$ & $(0.062)$ \\
\hline \multirow[t]{2}{*}{ ai3 } & -0.100 & $-0.160 * * *$ & $-0.134 * * *$ & 0.00668 & $0.157 * * *$ \\
\hline & $(0.073)$ & $(0.053)$ & $(0.041)$ & $(0.038)$ & $(0.047)$ \\
\hline \multirow[t]{2}{*}{ ai5 } & $0.186^{* *}$ & 0.0825 & 0.0376 & -0.0302 & $-0.203 * * *$ \\
\hline & $(0.078)$ & $(0.054)$ & $(0.040)$ & $(0.035)$ & $(0.046)$ \\
\hline \multirow[t]{2}{*}{ ai6 } & 0.141 & $0.146^{* *}$ & $0.205^{* * *}$ & 0.0555 & $-0.304 * * *$ \\
\hline & $(0.097)$ & $(0.069)$ & $(0.052)$ & $(0.045)$ & $(0.060)$ \\
\hline \multirow[t]{2}{*}{ ai7 } & $0.225^{* *}$ & $0.171 * *$ & $0.296 * * *$ & 0.0647 & $-0.365^{* * *}$ \\
\hline & $(0.10)$ & $(0.074)$ & $(0.058)$ & $(0.050)$ & $(0.066)$ \\
\hline \multirow[t]{2}{*}{ fs 1} & $-0.916^{* * *}$ & $-0.873 * * *$ & $-0.663 * * *$ & $-0.313 * * *$ & 0.102 \\
\hline & $(0.10)$ & $(0.090)$ & $(0.091)$ & $(0.11)$ & $(0.15)$ \\
\hline \multirow[t]{2}{*}{ fs2 } & $-0.393 * * *$ & $-0.385^{* * *}$ & $-0.366^{* * *}$ & $-0.275^{* * *}$ & -0.0317 \\
\hline & $(0.082)$ & $(0.064)$ & $(0.057)$ & $(0.063)$ & $(0.088)$ \\
\hline \multirow[t]{2}{*}{ fs 4} & $0.285^{* * *}$ & $0.361 * * *$ & $0.387 * * *$ & $0.267 * * *$ & 0.0265 \\
\hline & $(0.062)$ & $(0.042)$ & $(0.033)$ & $(0.031)$ & $(0.042)$ \\
\hline \multirow[t]{2}{*}{ fs 5} & $0.253 * * *$ & $0.434 * * *$ & $0.523 * * *$ & $0.516^{* * *}$ & $0.201 * * *$ \\
\hline & $(0.075)$ & $(0.053)$ & $(0.041)$ & $(0.037)$ & $(0.046)$ \\
\hline \multirow[t]{2}{*}{ Lag-SAH } & $0.103 * * *$ & $0.103 * * *$ & $0.103 * * *$ & $0.103 * * *$ & $0.103 * * *$ \\
\hline & $(0.026)$ & $(0.026)$ & $(0.026)$ & $(0.026)$ & $(0.026)$ \\
\hline \multirow[t]{2}{*}{ Age } & $-0.0480 * * *$ & $-0.0480 * * *$ & $-0.0480 * * *$ & $-0.0480 * * *$ & $-0.0480 * * *$ \\
\hline & $(0.0087)$ & $(0.0087)$ & $(0.0087)$ & $(0.0087)$ & $(0.0087)$ \\
\hline \multirow[t]{2}{*}{ educ2 } & 0.117 & 0.117 & 0.117 & 0.117 & 0.117 \\
\hline & $(0.11)$ & $(0.11)$ & $(0.11)$ & $(0.11)$ & $(0.11)$ \\
\hline \multirow[t]{2}{*}{ educ3 } & 0.119 & 0.119 & 0.119 & 0.119 & 0.119 \\
\hline & $(0.13)$ & $(0.13)$ & $(0.13)$ & $(0.13)$ & $(0.13)$ \\
\hline \multirow[t]{2}{*}{ educ4 } & -0.177 & -0.177 & -0.177 & -0.177 & -0.177 \\
\hline & $(0.23)$ & $(0.23)$ & $(0.23)$ & $(0.23)$ & $(0.23)$ \\
\hline \multirow[t]{2}{*}{ married } & 0.00827 & 0.00827 & 0.00827 & 0.00827 & 0.00827 \\
\hline & $(0.070)$ & $(0.070)$ & $(0.070)$ & $(0.070)$ & $(0.070)$ \\
\hline divsep & $-0.529 * * *$ & $-0.529 * * *$ & $-0.529 * * *$ & $-0.529 * * *$ & $-0.529 * * *$ \\
\hline
\end{tabular}




$\begin{array}{llllll} & (0.14) & (0.14) & (0.14) & (0.14) & (0.14) \\ \text { widowed } & 0.0466 & 0.0466 & 0.0466 & 0.0466 & 0.0466 \\ & (0.24) & (0.24) & (0.24) & (0.24) & (0.24) \\ \text { Lag- } & & & & \\ \text { unemployed } & 0.0908^{* *} & 0.0908^{* *} & 0.0908^{* *} & 0.0908^{* *} & 0.0908^{* *} \\ & (0.036) & (0.036) & (0.036) & (0.036) & (0.036) \\ \text { \# of kids } & 0.0490^{* *} & 0.0490^{* *} & 0.0490^{* *} & 0.0490^{* *} & 0.0490^{* *} \\ & (0.025) & (0.025) & (0.025) & (0.025) & (0.025) \\ \text { household size } & -0.0430^{* *} & -0.0430^{* *} & -0.0430^{* *} & -0.0430^{* *} & -0.0430^{* *} \\ & (0.021) & (0.021) & (0.021) & (0.021) & (0.021) \\ \text { Constant } & 1.011^{* * *} & 0.205 & -0.790^{* * *} & -2.085^{* * *} & -3.566^{* * *} \\ & (0.18) & (0.17) & (0.17) & (0.17) & (0.17) \\ \text { Obs } & 23712 & 23712 & 23712 & 23712 & 23712 \\ \text { Log-L } & -30469 & & & & \end{array}$

Standard errors in parentheses; $* * * \mathrm{p}<0.01, * * \mathrm{p}<0.05, * \mathrm{p}<0.1$

Note: coefficients on time dummies and regional dummies not reported 